\title{
Contemporary Trends in River Flow, Suspended Sediment Load, and Soil/Gully Erosion in the South of the Boreal Forest Zone of European Russia: The Vyatka River Basin
}

\author{
Artyom V. Gusarov ${ }^{1,2, *}$, Aidar G. Sharifullin ${ }^{3}$ and Achim A. Beylich ${ }^{4}$ \\ 1 Institute of Geology and Petroleum Technologies, Kazan Federal University, Kremlyovskaya Str. 18, \\ 420008 Kazan, Russia \\ 2 Federal and Regional Centre for Aerospace and Ground Monitoring of Objects and Natural Resources, \\ Belgorod State National Research University, Pobedy Str. 85, 308015 Belgorod, Russia \\ 3 Institute of Environmental Sciences, Kazan Federal University, Kremlyovskaya Str. 18, 420008 Kazan, Russia; \\ agsharifullin@kpfu.ru \\ 4 Geomorphological Field Laboratory (GFL), Strandvegen 484, 7584 Selbustrand, Norway; \\ achim.beylich@geofieldlab.com \\ * Correspondence: avgusarov@mail.ru
}

\section{check for}

updates

Citation: Gusarov, A.V.; Sharifullin, A.G.; Beylich, A.A. Contemporary Trends in River Flow, Suspended Sediment Load, and Soil/Gully Erosion in the South of the Boreal Forest Zone of European Russia: The Vyatka River Basin. Water 2021, 13, 2567. https://doi.org/10.3390/ w13182567

Academic Editors: Brigitta Schütt and Matjaž Mikoš

Received: 27 July 2021

Accepted: 13 September 2021

Published: 17 September 2021

Publisher's Note: MDPI stays neutral with regard to jurisdictional claims in published maps and institutional affiliations.

Copyright: (c) 2021 by the authors. Licensee MDPI, Basel, Switzerland. This article is an open access article distributed under the terms and conditions of the Creative Commons Attribution (CC BY) license (https:/ / creativecommons.org/licenses/by/ $4.0 /)$.
Abstract: Recent decades in the north of the East European Plain have been characterized by significant changes in climate and land use/cover, especially after the collapse of the USSR in 1991. At the same time, the hydrological consequences of these changes, especially changes in erosion processes and river sediment load, have been studied insufficiently. This paper partially covers this existing knowledge gap using the example of the Vyatka River basin. Draining an area of $129,000 \mathrm{~km}^{2}$, the Vyatka River is among the largest rivers in the boreal forest zone of European Russia. Cultivated land occupies about one-fifth of the river basin area; about three-fourths is covered by taiga forest vegetation. The results of state long-term hydrometeorological monitoring and information on land use/cover made it possible to reveal contemporary (since the 1960s) hydrological and erosion-intensity trends and their drivers within the greater $(96 \%)$ part of the river basin. There has been a statistically insignificant increase in water discharge in the Vyatka River basin during recent decades. This is due to a statistically insignificant increase (for the entire basin studied) in the spring snowmelt-induced floodwater flow and a statistically significant rise in the discharge in the year's warm and cold seasons. The main reason for the detected trends is increased precipitation, including heavy rainfall during the warm season. In contrast to this, the total annual suspended sediment load of the river (especially that which was snowmelt-induced) and, consequently, soil/gully erosion intensity have experienced a significant decrease in recent decades (up to 58\% between 1960-1980 and 2010-2018). Land-use/-cover changes (a reduction of cultivated land area and agricultural machinery, a decline of livestock in pastures) following the collapse of the Soviet Union are considered the main reasons for this decrease. The most noticeable changes in water discharge, suspended sediment load, and erosion intensity were observed in the most agriculturally developed southwest and south parts of the Vyatka River basin. All the above trends may be considered with a high probability to be representative for the south sector of the taiga zone of the East European Plain.

Keywords: large river; runoff; discharge; sediment yield; soil freezing; land-use change; land-cover change; abandoned land; climate change; taiga; East European Plain

\section{Introduction}

Recent decades in the western part of Northern Eurasia (within the former USSRthe Union of Soviet Socialist Republics) have been characterized by noticeable climate change [1-7], which influenced, among other things, the inter- and intra-annual distribution of the region's river water flow [8-13]. Since the beginning of the 1980s, there has been a 
considerable reduction in spring (snowmelt-induced) floodwater flow as a phase of the hydrological regime in most of the East European Plain. This reduction has been caused by an increase in winter air temperatures and the number and duration of thaws, as well as a decline in the depth of soil freezing by the end of winter. All this has resulted in a reduction in the pre-spring water storage in the snow (snow water equivalent) and a decrease in the maximum water discharge of the spring flood $[9,11,12]$. The reduction of the spring floodwater flow is most noticeable in the Don River basin and the Volga River basin's east, where the contribution of water flow during this phase of the hydrological regime has been reduced to $50 \%$ or less of the annual flow. In contrast, the spring floodwater flow in these basins accounted for $60-70 \%$ on average of the annual value in the first half of the 20 th century [11,14]. The reduction of snowmelt-induced floodwater flow has also been observed in recent decades in the western part of the forest zone of the East European Plain (the mixed forest zone), for example, in Estonia, Latvia, and Lithuania [15]. The low-water flow of the plain's rivers has significantly increased during the indicated period.

At the same time, in the northern part of the plain, there were multidirectional trends in the spring floodwater flow over the past 20 years. In the first half of the 1990s, in the Onega River, Sukhona River, and Vaga River, an increase in snowmelt-induced floodwater flow was noted, followed by a smooth return to the previous average values [9,12]. During this period, the Northern Dvina River and the Vychegda River basin's rivers differed, with stably increased spring floodwater flows. Slightly expressed trends in the decrease in the spring floodwater flow were detected in the rivers of the Pechora River basin's northern part. In other cases, they were insignificant.

The above-noted hydroclimatic changes could affect the current rates of soil/gully erosion in the region, since they reflect, first of all, the redistribution of surface and groundwater runoff caused by changes in the depth of soil freezing under global warming. Moreover, the impact of these changes on erosion processes in river basins was supplemented by changes in land use/cover after the collapse of the USSR in 1991-a reduction in cultivated land (as the most erosion-hazardous area in river basins), especially noticeable in the 1990s and the early 2000s, primarily in the administrative regions of European Russia with ineffective agriculture in the forest landscape zone [16-20]. According to our estimates, from 1970-1987 to 1996-2017, the total cultivated land declined, for example, in the Leningrad Oblast (by 37\%), the Novgorod Oblast (by 56\%), the Kostroma Oblast (by 51\%), the Perm Oblast (Krai) (by 47\%), etc. [21] The research team from Lomonosov Moscow State University [22] has estimated the probable soil erosion for administrative regions of European Russia based on erosion models. According to this modeling, the relative reduction of the rates of soil erosion in the regions of the northern half of the East European Plain (the taiga zone) between 1980 and 2012-2014 were: in the Leningrad Oblast, 53\%; in the Novgorod Oblast, 77\%; in the Pskov Oblast, $87 \%$; in the Tver Oblast, $82 \%$; in the Kostroma Oblast, $84 \%$; in the Vologda Oblast, $72 \%$; in the Komi Republic, 70\%; in the Arkhangelsk Oblast, $80 \%$; in the Perm Oblast (Krai), $81 \%$; in the Udmurt Republic, $63 \%$; etc.

In the presence of these model estimates, there are still no representative results of long-term field observations of the current rates of soil/gully erosion in this region, including confirming modeling results. The only exceptions are the relatively reliable results of monitoring of the retreat of gully head-cuts (since 1978) in the extreme south of the taiga zone of the east of the plain within the Udmurt Republic [23]. However, for such a large region as the northern part of the plain, these are more than unsatisfactory results. Soil-erosion surveys, which were organized regularly during the late Soviet Union period, have not been carried out in the region in recent decades [24]. Consequently, there is currently no reliable answer to the question of what has been the response of soil/ravine erosion processes to current hydroclimatic and land-use changes in such a vast region of Eastern Europe. This is an obstacle to constructing a general concept of modern directed changes in soil/gully erosion within the entire territory of the East European Plain. The analysis of contemporary trends in soil/gully erosion, in addition to the known applied value, also has geoecological applications, since these trends largely determine 
changes in the turbidity of rivers and temporary streams, and pollutants entering rivers with sediments (erosion products) affect the quality of river waters, the rates of siltation of natural and artificial water bodies in river basins, etc. The solution to the above issues is essential for the southern "belt" of European Russia's taiga zone, which is economically more developed and more populated than the rest of the plain's northern half.

Below, using the example of the Vyatka River basin (Figure 1), which is one of the largest rivers in the south of the taiga zone of European Russia, we reveal contemporary (over the past 60 years) trends in water flow and erosion processes (based on data on the temporal variability of river suspended sediment load) and their driving factors. With a high probability, the results obtained can be regarded as representative for the entire south sector of the East European Plain's boreal forest (taiga) zone.

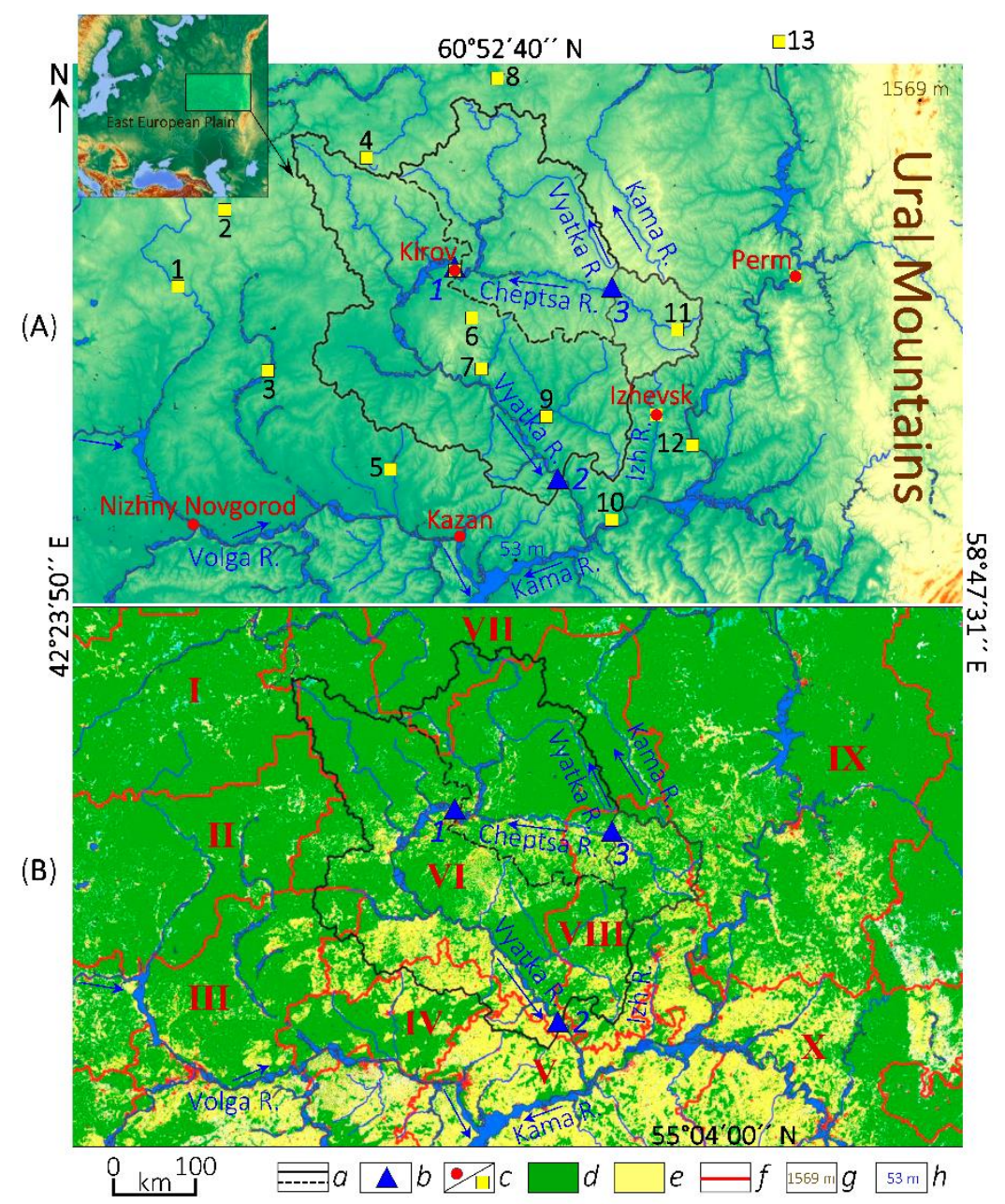

Figure 1. The location of the Vyatka River basin on physical (A) and land-cover (B) maps. $a$-the basin (sub-basin) boundary; $b$ - the analyzed hydrological stations at: 1-Kirov, 2-Vyatskiye Polyany, and 3-Glazov; $c$ - cities and the analyzed meteorological stations in: 1-Kologriv, 2-Nikol'sk, 3-Vetluga, 4-Oparino, 5-Yoshkar Ola, 6-Kumiony, 7-Nolinsk, 8-Koigorodok, 9-Kilmez', 10Yelabuga, 11-Debessy, 12-Sarapul, and 13-Cherdyn'; $d$-forestland; $e$-arable land; $f$-boundaries of Russia's administrative regions: I—Vologda Oblast, II—Kostroma Oblast, III—Nizhny Novgorod Oblast, IV-Mari El Republic, V-Republic of Tatarstan, VI-Kirov Oblast, VII-Komi Republic, VIII-Udmurt Republic, IX-Perm Krai, and X-Republic of Bashkortostan; g-the Konzhakovskiy Kamen summit of the Northern Ural, the highest elevation of the region shown on the map; $h$-the average long-term level of the Kuybyshev Reservoir, the lowest elevation on the Earth's surface of the region shown on the map. 


\section{Materials and Methods}

\subsection{The Vyatka River and Its Basin}

Flowing in the eastern part of the East European Plain, the Vyatka River is the largest right-bank tributary of the Kama River, the largest tributary of the Volga River. The length of the river is $1314 \mathrm{~km}$; the total basin area is $129,000 \mathrm{~km}^{2}$. The river begins on the Upper Kama Upland with a maximum elevation of $337 \mathrm{~m}$ a.s.l., in the north of the Udmurt Republic (see Figure 1). The elevation of the river's source $\left(58^{\circ} 26^{\prime} 51.72^{\prime \prime} \mathrm{N}, 52^{\circ} 10^{\prime} 35.4^{\prime \prime} \mathrm{E}\right)$ is about $240 \mathrm{~m}$ a.s.l. The Vyatka River flows into the Kuybyshev Reservoir of the lower Kama River. The river mouth's elevation $\left(55^{\circ} 35^{\prime} 41.99^{\prime \prime} \mathrm{N}, 51^{\circ} 29^{\prime} 54.24^{\prime \prime} \mathrm{E}\right)$ is about $53 \mathrm{~m}$ a.s.1.

According to the intra-annual discharge distribution, the Vyatka River belongs to the group of rivers with a well-noted spring (snowmelt-induced) flood. The river freezes in November; the breaking of the river ice occurs in April. During the spring flood period, more than $80 \%$ of the annual water flow passes. Based on our calculations, the average long-term water discharge (WD) in the lower course of the river near the town of Vyatskiye Polyany (the basin area is $124,000 \mathrm{~km}^{2}$, see Figure 1) is $921 \mathrm{~m}^{3} \mathrm{~s}^{-1}$, or $7.41 \mathrm{~s}^{-1} \mathrm{~km}^{-2}$. Since the late 1970s, there has been a statistically significant increase in the river's average annual WD compared to previous decades after 1920 (Figure 2; see Appendix A, Figure A1). This increase is mainly owing to a rise in WD during the non-spring-flood months of the year, from July to March (see Appendix A, Figure A2). The noted changes can be considered a historical hydrological background for contemporary (recent decades) changes in water discharge and sediment load in the river basin. The average annual suspended sediment load (SSL) of the river at Vyatskiye Polyany during 2010-2018 was $58 \mathrm{~kg} \mathrm{~s}^{-1}$, or 1.83 million $\mathrm{Mg} \mathrm{y}^{-1}\left(14.8 \mathrm{Mg} \mathrm{km}^{-2} \mathrm{y}^{-1}\right)$.

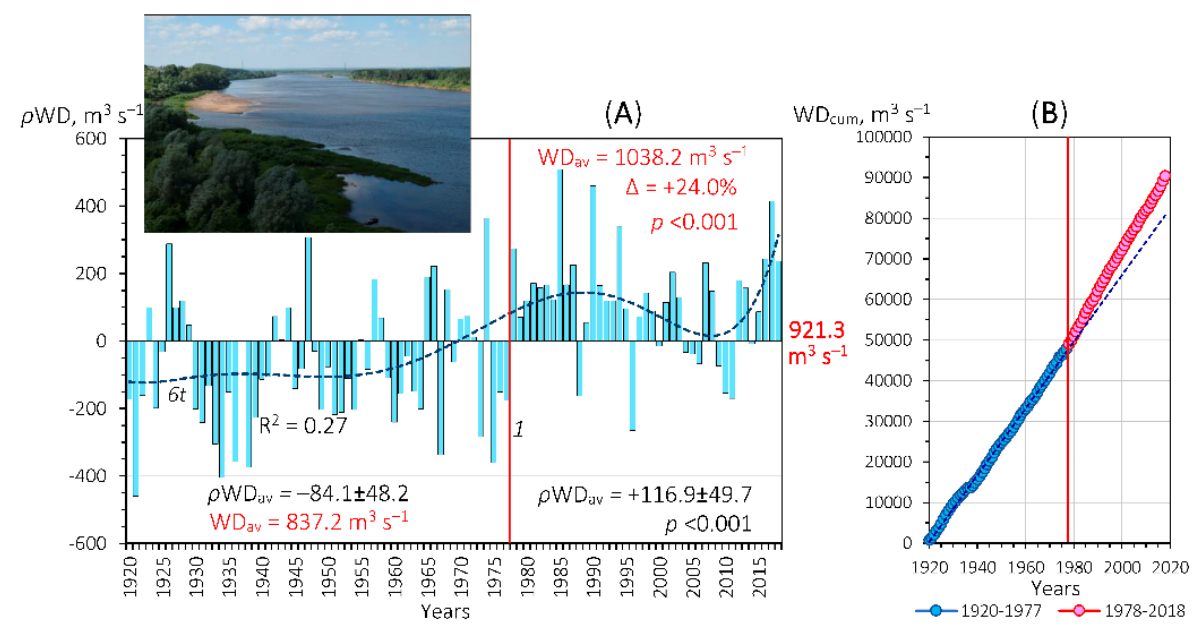

Figure 2. Changes in the Vyatka River's average annual water discharge (WD) at Vyatskiye Polyany (see Figure 1) from 1920 to 2018. (A-differences in WD ( $\rho W D)$ relative to the discharge averaged for the entire period $\left(921.3 \mathrm{~m}^{3} \mathrm{~s}^{-1}\right)$; (B)—cumulative WD $\left(\mathrm{WD}_{\text {cum }}\right) ; \rho \mathrm{WD}_{\mathrm{av}}$-average $\rho \mathrm{WD}$ for the periods; $\mathrm{WD}_{\mathrm{av}}$-average $\mathrm{WD}$ for the periods; $\Delta$-relative change; $\mathrm{R}^{2}$ — the coefficient of determination of a sixth-degree polynomial trend (6t). The photo, taken on 19 June 2021, shows the Vyatka River at Lebyazhy (57.42387 N; 49.52030 E, almost halfway between Kirov and Vyatskiye Polyany along the river). Note: The time border $(1977 / 1978,1)$ between the two periods was found using the "Changepoint detection" and "Changepoints analysis" methods in the statistical analysis and programming environment $R$.

The Vyatka River basin occupies a vast plain composed of Permian, lower Triassic, and Jurassic rocks (mainly clays, sands, sandstones, marls, limestones, and dolomites) overlapped by loose polygenetic Quaternary deposits [25]. The river basin is located within the moderate continental climate zone. The slightly hilly relief and the absence of mountain barriers allow the free penetration and movement of air masses. The basin is influenced 
by humid cyclones from the Atlantic Ocean, cold air masses from the Arctic, and dry air masses from Western and Central Asia. According to our calculations, average annual temperatures vary from 2 to $5{ }^{\circ} \mathrm{C}$. Yearly precipitation decreases from $650-700 \mathrm{~mm}$ in the north to about $550 \mathrm{~mm}$ in the south of the river basin. Annual evapotranspiration is about $60 \%$ of yearly precipitation. The snowpack depth in the basin varies from 70 to $30 \mathrm{~cm}$. The duration of the snowpack period ranges from 160 days in the north to 140 days or less in the south [25]. Since the late 1970s, the Vyatka River basin has experienced a statistically significant increase in the average annual air temperature and annual precipitation and a decrease in their intra-annual amplitudes compared to previous decades after 1920 (Figure 3). Moreover, in the cold season, the relationship between the changes in temperature and precipitation was direct, although statistically insignificant. In contrast, in the warm season, this relationship was reversed (see Appendix A, Figure A3).
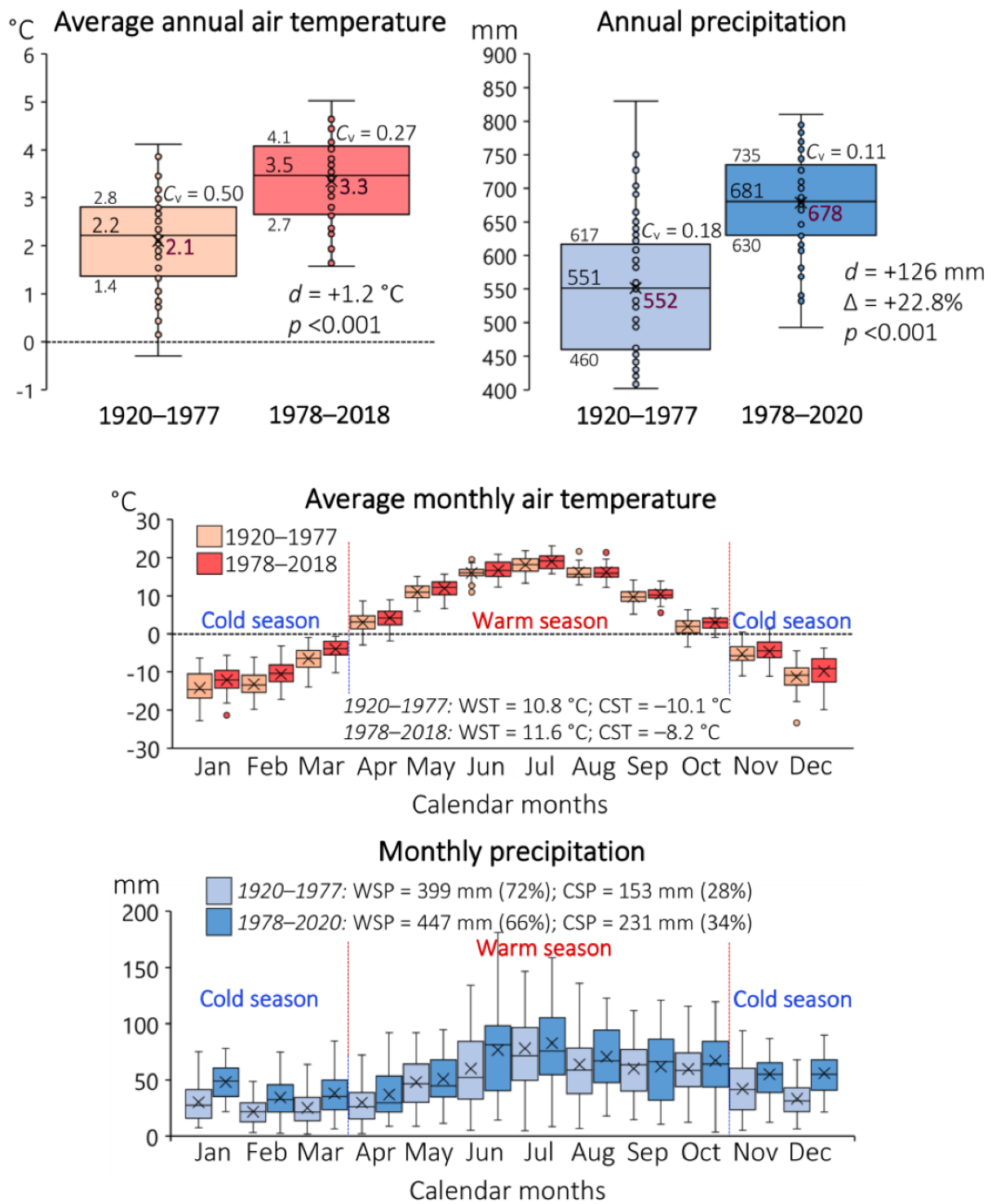

Figure 3. Annual and monthly air temperature and precipitation at a meteorological station in Kirov (see Figure 1) from 1920 to 2020. $C_{\mathrm{v}}$ 一the coefficient of inter-annual variation; inter-period changes: $d$-absolute, $\Delta$-relative; $p$-statistical probability of the changes; WST (CST)-average warm-season (cold-season) temperature; WSP (CSP) — the warm-season (cold-season) precipitation and their annual share (in parentheses). Note: Precipitation data for 1936-1939 were not available. 
The northern and central parts of the Vyatka River basin belong to the territories with excessive moisture; the southern part is the area of sufficient moisture. Most of the basin is occupied by taiga vegetation. To the south, dark-coniferous taiga forests on sod-podzolic soils are replaced by dark-coniferous broadleaf mixed forests and meadows on sod-podzolic soils and light-gray forest soils [25]. The extreme southern part of the basin is situated in the forest-steppe zone with gray and dark-gray forest soils and even leached and podzolized chernozems. The Vyatka River basin, chiefly its southern half, is a territory with relatively intensive economic activities. Crop production is dominated by the cultivation of cereals, perennial and industrial crops, and vegetables. The sub-basin of the middle and lower courses of the river is comparatively less forested and more plowed (Figures 1 and 4). The Vyatka River basin is divided between nine administrative regions of the Russian Federation, of which the Kirov Oblast and the Udmurt Republic occupy 88.6\% of the basin's total area (68.7\% and $19.9 \%$, respectively). The rest of the basin is located in the Komi Republic, Mari El Republic, Nizhny Novgorod Oblast, Republic of Tatarstan, Perm Krai, Vologda Oblast, and Kostroma Oblast (see Figure 1).

(A)

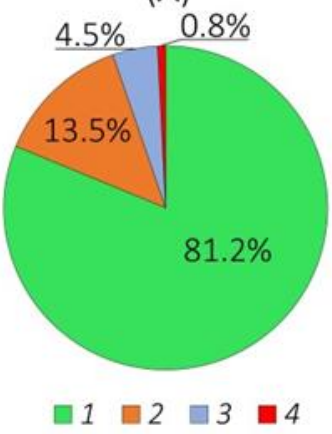

(B)

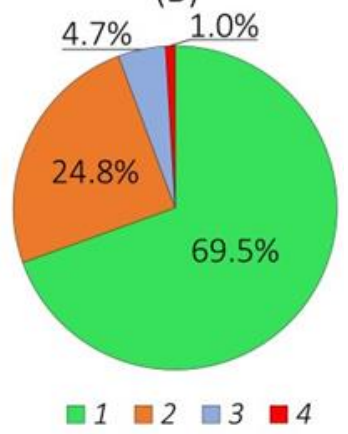

Figure 4. Land-cover structure in the Vyatka River basin in 2015. The sub-basins: (A)—upriver of Kirov, (B) - upriver of Vyatskiye Polyany to Kirov (see Figure 1). 1-forestland, 2—cultivated land, 3-grassland, 4-other, including wetlands and urbanized territories.

\subsection{Data and Their Sources}

\subsubsection{Hydrological Data}

To assess contemporary trends in river WD and SSL, as well as the intensity of overall erosion processes within the Vyatka River basin, the study used the results of long-term monitoring at two hydrological (gauging) stations at the city of Kirov and the town of Vyatskiye Polyany, located along the middle and lower courses of the river, respectively (see Figure 1, Table 1). In addition, data on WD and SSL of the Cheptsa River (near the town of Glazov), the largest left-bank tributary of the Vyatka River, were collected and studied. The analyzed river basin's total area is $124,000 \mathrm{~km}^{2}$ (upriver of Vyatskiye Polyany), or about $96 \%$ of the Vyatka River basin's total area.

Table 1. Analyzed gauging stations in the Vyatka River basin.

\begin{tabular}{ccccc}
\hline \multirow{2}{*}{ River } & Gauging Station at: & \multicolumn{3}{c}{ Characteristics } \\
\cline { 3 - 5 } & & $\mathbf{D ,} \mathbf{~ k m}$ & $\boldsymbol{F}, \mathbf{k m}^{\mathbf{2}}$ & $\boldsymbol{H}, \mathbf{~ m} \mathbf{( B H S - K )}$ \\
\hline Vyatka & Kirov & 692.0 & 48,300 & 103.19 \\
Vyatka & Vyatskiye Polyany & 100.0 & 124,000 & 54.83 \\
Cheptsa & Glazov & 284.0 & 9750 & 133.70 \\
\hline
\end{tabular}

$\bar{D}$-distance from the river's mouth; $F$-river basin area; $H$-zero water level (BHS-K-Baltic height system at Kronstadt). NB: The selected gauging stations are characterized by the longest monitoring series of water discharge and, especially, suspended sediment load in the entire Vyatka River basin.

The state hydrological monitoring data are available from hydrological collections of the former USSR [26-29], the webpage of Lomonosov Moscow State University "Water 
Regime of the Rivers of European Russia" (http:/ / autolab.geogr.msu.ru/hydrograph/\#, accessed on 27 April 2021), and the automated information system of state monitoring for water bodies (http:/ /gmvo.skniivh.ru, accessed on 15 May 2021) from the Federal Agency for Water Resources of the Ministry of Natural Resources and Environment of the Russian Federation.

The WD data collected were summarized in the long-term series on average annual and average monthly discharge $\left(\mathrm{m}^{3} \mathrm{~s}^{-1}\right)$ at the aforementioned hydrological stations. Observations for the discharge of the rivers of the former USSR and modern Russia were carried out based on a single standard program, several times daily (mainly by converting water level into discharge). At the main hydrological stations of the study on the Vyatka River at Kirov and Vyatskiye Polyany, the data covered the period from 1940 to 2018, except for 1943, 1944, and 2009 at Kirov. The WD data of the Cheptsa River were presented for two periods with different durations-from 1937-1985 and 2010-2018. The large gap from 1986 to 2009 is due to the lack of available data.

The SSL data collected for the Vyatka River were summarized in the long-term monitoring series of average annual and maximum average monthly load $\left(\mathrm{kg} \mathrm{m}^{-3}\right)$ for the aforementioned hydrological stations. According to [30], the average error in estimating the mean annual values of the load in gauging stations in the former USSR was up to $25 \%$. It could probably have somewhat increased in recent decades due to insufficient funding of hydrological monitoring in the country. When compiling hydrological collections and reports of the Hydrometeorological Service of the former USSR and modern Russia, the average annual and monthly suspended sediment loads were calculated from the concentration of suspended sediment of the water received during the main phases of the hydrological regime. At the main hydrological stations of the study on the Vyatka River at Kirov and Vyatskiye Polyany, the load data covered 1940-1985 (except for a few years in the 1940s and 1960s) and 2010-2018. The SSL data on the Cheptsa River additionally collected are presented for two periods with different duration-1950-1980 (except for nine years) and 2014-2018. The large gap from 1981 to 2013 is also due to the lack of available data.

\subsubsection{Climate Data}

Long-term data on monthly/annual air temperature and precipitation for the periods studied (1960/1966-1980 and 2010-2019) were collected from 13 regional meteorological stations (see Figure 1). In addition, for the stations in the towns/cities of Kologriv, Nolinsk, Sarapul, and Perm, reliable information on long-term changes in topsoil temperature and water storage in the snow (snow water equivalent) during the first ten days of April (1963-2012 with numerous interruptions due to lack of data) were also collected and processed. All of these data are available from the All-Russia Research Institute of HydroMeteorological Information-World Data Center, RIHMI-WDC (https: / /www.meteo.ru, accessed on 27 April 2021), and "NCEI Climate Data Online. Global Summary of the Month (Average Temperature and Precipitation for 1920-2019)" (https:/ / www.ncdc.noaa.gov / cdo-web/, accessed on 27 April 2021).

\subsubsection{Land Use/Cover Data}

Information on the distribution of cultivated land area within the Kirov Oblast and the Udmurt Republic, where the predominant part of the Vyatka River basin is located, for different time intervals (during the late USSR period (1960-1970, 1975, 1980, 1985, 1986, 1987, 1990, and 1991) and the post-USSR period (annually from 1992 to 2018) was collected and analyzed. These data made it possible to semi-quantitatively assess the probable human (mainly agricultural) impact on long-term temporal dynamics in WD, SSL, and erosion intensity. The data were detailed for principal crops such as cereals, perennial, and annual crops that used to occupy and still occupy about $85-90 \%$ of the total cropland area in the regions. The sources of this information are statistical collections (bulletins) of the former USSR [31-35] and also electronic statistical resources of the Russian Federation (https: / / fedstat.ru, https:/ /gks.ru, accessed on 10 May 2021). 
Relevant information on the Kirov Oblast and the Udmurt Republic for all types of farms from 1953 to 2019 with numerous interruptions due to lack of data was also collected to assess the potential impact of livestock (cattle, sheep, and goats) on temporal changes in the above-mentioned hydrological variables. The sources of this information are [31-34] and electronic statistical resources of the Russian Federation (https: / / fedstat.ru, accessed on 10 May 2021).

In addition, information on the annual amount of main (heavy) agricultural machinery (tractors and grain combine harvesters) in the Kirov Oblast and the Udmurt Republic for all types of farms for 1970-1975 [31,32] and 1990-2019 (https:/ / fedstat.ru, accessed on 10 May 2021) was collected and processed to identify the dynamic of the "load" of this machinery on cropland within the administrative region during these periods.

\subsection{Methods}

\subsubsection{Hydrological Data Processing}

The above hydrological variables were averaged over two periods-1960-1980 (as a base period) and 2010-2018. On the one hand, the second period fell due to the most considerable modern climate change in the region, while the first period was relatively weakly affected by this change. On the other hand, the period of 1960-1980 and the early 1980s were the years of the most significant development of agriculture in the entire history of Russia [24]. In the last decade, this development has been at its lowest level for at least the past 60 years. Thus, comparing the analyzed hydrological characteristics between the periods allows revealing the tendencies in hydrological and erosion processes with a complex combination of climate and land-use/-cover changes and makes it possible to identify the leading causes of these processes' changes.

Along with calculating averaged long-term values, the specific values of average annual and maximum (per annum) WD were also calculated for each analyzed period: $\triangle W D$-differentiated specific WD $\left(1 \mathrm{~s}^{-1} \mathrm{~km}^{-2}\right)$ upriver of the corresponding hydrological station for the corresponding monitoring period (Equation (1)):

$$
\Delta \mathrm{WD}_{\mathrm{i}}=\left(\mathrm{WD}_{\mathrm{i}}-\mathrm{WD}_{\mathrm{i}+1}\right) /\left(S_{\mathrm{i}}-S_{\mathrm{i}+1}\right),
$$

$\mathrm{WD}_{\mathrm{i}}\left(1 \mathrm{~s}^{-1}\right)$-average $\mathrm{WD}$ of a river at a hydrological station $i$ (with a total basin area $S_{\mathrm{i}}\left(\mathrm{km}^{2}\right)$ upriver of this station); and $\mathrm{WD}_{\mathrm{i}+1}\left(\mathrm{l} \mathrm{s}^{-1}\right)$-average $\mathrm{WD}$ of the river at the nearest hydrological station $(i+1)$ located upriver (with a total basin area $S_{i+1}\left(\mathrm{~km}^{2}\right)$ upriver of this station). ( $\left.W D_{i}-W D_{i+1}\right)$ represents differentiated $W D(d W D) . \Delta W D_{i}$ allows identifying the areas (sub-basins) of the most intense water runoff and its year-to-year variability in a particular river sub-basin.

Along with calculating averaged long-term values, the specific values of average annual and maximum average monthly SSL were also calculated for each analyzed period: $\triangle$ SSY-differentiated specific SSL $\left(\mathrm{Mg} \mathrm{km}^{-2} \mathrm{y}^{-1}\right)$ upriver of the corresponding hydrological station for the corresponding monitoring period (Equation (2)):

$$
\Delta \mathrm{SSY}_{\mathrm{i}}=\left(\mathrm{SSL}_{\mathrm{i}}-\mathrm{SSL}_{\mathrm{i}+1}\right) /\left(S_{\mathrm{i}}-S_{\mathrm{i}+1}\right),
$$

$\mathrm{SSL}_{\mathrm{i}}\left(\mathrm{Mg} \mathrm{y}^{-1}\right.$ or $\mathrm{Mg}$ month $^{-1}$ )—annual (or monthly) SSL of a river at a hydrological station $i$ (with a total basin area $S_{\mathrm{i}}\left(\mathrm{km}^{2}\right)$ upriver of this station); and $\mathrm{SSL}_{\mathrm{i}+1}\left(\mathrm{Mg} \mathrm{y}^{-1}\right.$ or $\mathrm{Mg}$ month $^{-1}$ ) - annual (monthly) SSL of the river at the nearest hydrological station $(i+1)$ located upriver (with a total basin area $S_{i+1}\left(\mathrm{~km}^{2}\right)$ upriver of this station). (SSL $\mathrm{SL}_{\mathrm{i}}-$ SSL $_{i+1}$ ) represents differentiated SSL (dSSL). $\Delta$ SSY $_{i}$ allows identifying the areas (sub-basins) of the most intense sediment formation (mechanical denudation, including primarily sheet/rill/gully erosion) and its year-to-year variability in a particular river sub-basin.

River sediment load/yield was/is widely used in world practice to estimate the temporal variability of erosion (more broadly-mechanical denudation) intensity in fluvial systems of various scales [14,36-43], despite some methodological flaws. At the same time, sediment load/yield cannot serve as an absolute measure of all erosion products 
due to a complex mechanism for delivering sediment from erosion (sediment-mobilized) areas to riverbeds. This delivery depends on a large set of factors such as geological structure, morphometry/morphology of slopes, the density of permanent and temporary streams, basin area, climatic characteristics, features of natural landscapes, and the nature of their anthropogenic transformation [14,44-48]. This is especially important to consider when assessing the spatial heterogeneity of erosion (mechanical denudation) intensity. However, the importance and accuracy of sediment yield/load as an indicator of the temporal dynamics of erosion (mechanical denudation) increases noticeably when assessing the overall variability of erosion intensity within any one river basin for different time intervals - the temporal dynamics of sediment load/yield relative to one gauging station.

\subsubsection{Climate Data Processing}

The collected meteorological data made it possible to calculate the average annual air temperature and the early spring period temperature (March and April), when there is active preparation for snow melting (March) and an intense snow melting process occurring in most of the Vyatka River basin. The data were averaged over two periods (1960-1980 and 2010-2019) at 12 meteorological stations. For 13 meteorological stations analyzed, the average values of annual precipitation and precipitation of the warm season (April to October) were calculated for 1966-1980 and 2010-2019. In addition, for four analyzed meteorological stations, the long-term average values of water storage in the snow (snow water equivalent) in the first ten days of April in 1966/1969-1980 and 2010-2019 were calculated.

The annual runoff coefficient $(R C)$ as the ratio between annual water runoff depth $\left(\mathrm{mm} \mathrm{y}^{-1}\right)$ (based on the above-mentioned differentiated specific water discharge) and annual precipitation $\left(\mathrm{mm} \mathrm{y}^{-1}\right.$ ) (see below for selected meteorological stations) was calculated for the two analyzed sub-basins. The calculated $R C$-values were averaged over two periods-1966-1980 and 2010-2018.

\subsubsection{Land-Use/-Cover Data Processing}

To assess the role of land-cover changes in long-term hydrological and erosion changes, the integral crop management factor ( $C$-factor) [49]), or $\Sigma C$, was calculated for the warm season, May to October, for the analyzed periods in the Kirov Oblast and the Udmurt Republic. The $\Sigma C$-factor is a weighted average that considers both the area occupied by one or another crop in the corresponding period and the crop's individual $C$-factor. The $\Sigma C$-index was calculated only for cereals, perennial, and annual crops according to Equation (3). The total area under these crops is/was $85 \%+$ of the total sown area of the studied regions.

$$
\Sigma C=\left(C_{1} \times F_{1}+C_{2} \times F_{2}+\ldots+C_{\mathrm{n}} \times F_{\mathrm{n}}\right) /\left(F_{1}+F_{2}+\ldots+F_{\mathrm{n}}\right),
$$

$C_{1}, C_{2} \ldots C_{n}$ represent individual $C$-factors for different analyzed crops $(0.016$ for natural meadow vegetation (almost the same for an abandoned land), 0.02 for perennials, 0.48 for cereals, and 0.48 for annuals), averaged over the warm season; i.e., it is the average of the monthly averages from May to October [44]. From November to early April, the cold period is a season with almost no liquid precipitation (mainly snow precipitation) and reliable soil protection with a snowpack in the studied administrative regions. Because of this, the $\Sigma$ C-index was not calculated for the months of the cold period. $F_{1}, F_{2} \ldots F_{\mathrm{n}}$ represent the average areas occupied by these crops in the corresponding period. The $\Sigma \mathrm{C}$-index varies from 0 to 1 . The lower the index, the better the plowed soils in the analyzed administrative regions are protected against rainfall-induced soil erosion. At the beginning and the end of the sowing season, the soil in the study region is poorly protected by cultivated vegetation against rain-induced erosion; i.e., $C$ is close to 1 . Due to this, the $\Sigma C$-values averaged over the warm season are somewhat overestimated compared to the summer months. 
The agricultural machinery load $(\tau)$ on cultivated land within the Kirov Oblast and the Udmurt Republic for 1970-1975 and 1990-2019 was calculated based on Equation (4):

$$
\tau=n / F,
$$

where $n$ is the total amount (units) of tractors or grain combine harvesters for the corresponding year and $F$ is thecultivated land area (ha) for the corresponding year: for tractors, the total area of cultivated land, and for grain combine harvesters, only sown areas for grain crops.

To identify statistically significant differences in all averaged values of the studied land-cover and hydrometeorological variables between the monitoring periods, Student's t-test was used. All the averaged values were calculated with a $95 \%$ confidence interval.

\section{Results}

\subsection{Hydrological Changes}

Between 1960-1980 and 2010-2018, the average annual WD of the Vyatka River tended to increase, but these trends were not statistically significant (Figure 5). Moreover, this detected increase was greatest in the lower course of the river.

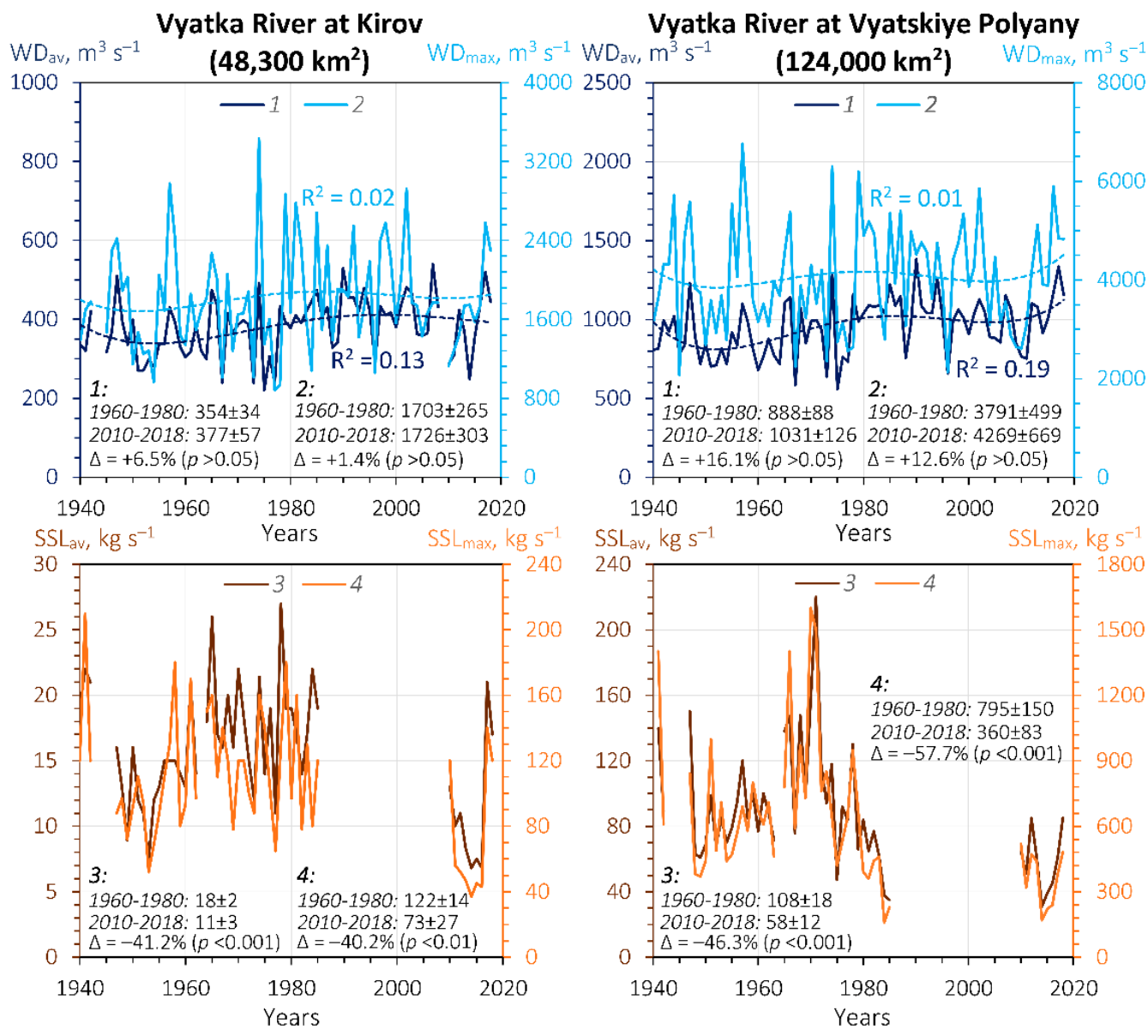

Figure 5. Changes in water discharge (WD) and suspended sediment load (SSL) of the Vyatka River from 1940 to 2018 (according to [21]). WD $\mathrm{Wv}_{\mathrm{av}}$-average annual WD (1), WD max-maximum

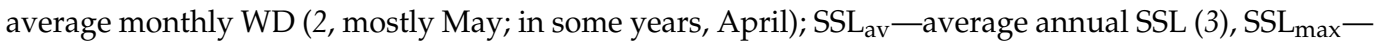
maximum average monthly SSL ( 4 , May or April); $\Delta$-relative change; $\mathrm{R}^{2}$ - the coefficient of determination of a fourth-degree polynomial trend (the dashed line). 
Despite lacking accurate data on the inter-annual variability of the river flow during the spring (caused by snow melting) flood, we can nevertheless state that this flow also gradually increased between the indicated periods. We draw this conclusion from the longterm river flow variability during the month with the maximum water discharge (May; in some years, April) (see Figure 5). However, in this case, the trends were also not statistically significant. It is noteworthy that, on the one hand, the increase in snowmelt-induced WD was less than in the case of the average annual WD. On the other hand, the increase in snowmelt-induced discharge was also greatest in the river's lower course (see Figure 5).

Long-term changes in the Vyatka River's SSL considerably differed from those experienced by WD of this river. The river's SSL, both the annual average and the maximum average monthly, was statistically significantly lower in the last decade than during the 1960s-1970s, the period of the highest sediment load for the last 80 years (at least) in the Vyatka River basin (see Figure 5). Moreover, this decrease was also more noticeable in the lower course of the river. It is necessary to pay attention to two more features. First, the maximum average monthly sediment load of the river in its lower course decreased significantly more than at the city of Kirov. Second, the reduction in both the average annual and the maximum average monthly SSL began in the river's lower course from the very beginning of the 1980s, while at Kirov, it began most likely in the late 1980s or even later.

The long-term dynamics of WD and SSL noted above reflected the changes that occurred in their specific values, differentiated relative to the area of the river sub-basins. We report an increase in the differentiated specific average annual WD in the two analyzed sub-basins. Moreover, WD was the greatest and statistically significant only in the sub-basin of the river upstream of Vyatskiye Polyany to Kirov (Figure 6A).

There was also a more or less proportional increase in the differentiated maximum average monthly WD, but this was statistically insignificant (Figure 6B). As for the differentiated yield of suspended sediment, we note its statistically significant and more noticeable decrease (almost half or more) in the sub-basin between Vyatskiye Polyany and Kirov compared to the sub-basin located upriver (Figure 6C,D). Considering the indicated changes in SSL/SSY, there was a reduction in contrast in the differentiated SSY between the two sub-basins of the Vyatka River basin from 1960-1980 to 2010-2018 (Figure 6C,D).

There was also some change in SSL structure in the lower course of the Vyatka River between the analyzed periods. Compared to 1960-1980, during the period 2010-2018, there was a slight increase in SSL of transit origin, i.e., sediment brought downriver from the overlying sub-basin (Table 2). Despite this, the share of so-called local SSL formed by the products of soil-gully erosion and riverbed deformations still remains significant (about $80 \%)$ in the river's lower course.

The ratio between the differentiated maximum average monthly WD and SSL in each of the two sub-basins from 1940 to 2018 made it possible to identify three different groups of years: years of relatively normal SSL and years of anomalously high and low sediment load (Figure 7). The proportion of years with anomalously relatively low sediment load in the sub-basin upriver of Kirov and the sub-basin located between Kirov and Vyatskiye Polyany was almost the same $(25 \%$ and $21 \%$ of the total number of paired years of observations, respectively). In comparison, anomalously relatively high sediment load was more frequent in the second sub-basin than in the first sub-basin ( $45 \%$ and $21 \%$, respectively).

Despite this, there were years when anomalously high maximum average SSL was observed for the entire river basin-1941, 1961, 1965, 1967, and 2010. Several years of anomalously relatively low maximum average monthly SSL $(1955,1985,2013,2014,2015$, and 2016) were also typical for the entire studied basin. A reduction in the correlation's tightness between the indicated WD and SSL from the upper sub-basin to the lower one was noted (see Figure 7). It is also noteworthy that the closest correlation of WD was observed concerning the conventionally "normal" (average) sediment load and the smallest—for anomalously high load. 


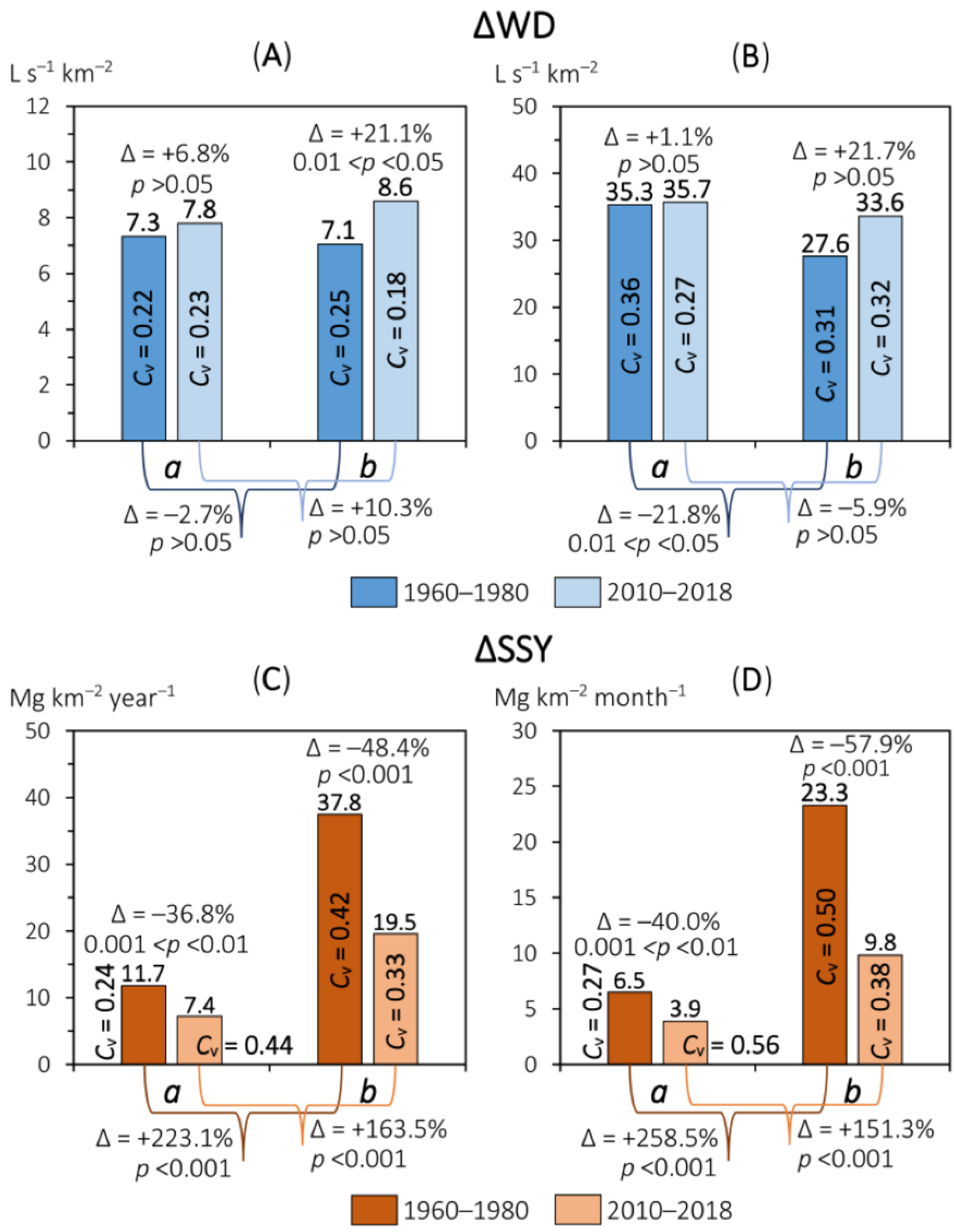

Figure 6. Changes in differentiated specific water discharge $(\triangle \mathrm{WD})$ and suspended sediment yield ( $\triangle$ SSY) in the Vyatka River basin between 1960-1980 and 2010-2018. (A)-average annual $\Delta W D$; (B)-maximum average monthly $\Delta \mathrm{WD}$; (C)—annual $\Delta$ SSY; (D)-maximum monthly $\Delta S S Y$; the sub-basins: $a$-upriver of Kirov, $b$ - upriver of Vyatskiye Polyany to Kirov (see Figure 1 ); $C_{\mathrm{v}}$-the coefficient of inter-annual variation; $\Delta$-relative change.

Table 2. Changes in the origin of suspended sediment load (SSL) within the two analyzed sub-basins of the Vyatka River between 1960-1980 and 2010-2018.

\begin{tabular}{ccccccccc}
\hline & \multicolumn{4}{c}{ Annual SSL } & \multicolumn{3}{c}{ Maximum Monthly SSL } \\
\cline { 2 - 9 } SSL Origin & \multicolumn{2}{c}{ Sub-Basin I ${ }^{\mathbf{1}}$} & \multicolumn{2}{c}{ Sub-Basin II ${ }^{\mathbf{2}}$} & \multicolumn{2}{c}{ Sub-Basin I ${ }^{\mathbf{2}}$} & Sub-Basin II $^{\mathbf{2}}$ \\
\cline { 2 - 10 } & $\mathbf{1 9 6 0 - 1 9 8 0}$ & $\mathbf{2 0 1 0 - 2 0 1 8}$ & $\mathbf{1 9 6 0 - 1 9 8 0}$ & $\mathbf{2 0 1 0 - 2 0 1 8}$ & $\mathbf{1 9 6 0 - 1 9 8 0}$ & $\mathbf{2 0 1 0 - 2 0 1 8}$ & $\mathbf{1 9 6 0 - 1 9 8 0}$ & $\mathbf{2 0 1 0 - 2 0 1 8}$ \\
\hline Local, \% & 100.0 & 100.0 & 83.3 & 81.0 & 100.0 & 100.0 & 84.7 & 79.7 \\
Transit, \% & - & - & 16.7 & 19.0 & - & - & 15.3 & 20.3 \\
\hline
\end{tabular}

${ }^{1}$ Upriver of Kirov; ${ }^{2}$ Upriver of Vyatskiye Polyany to Kirov. 


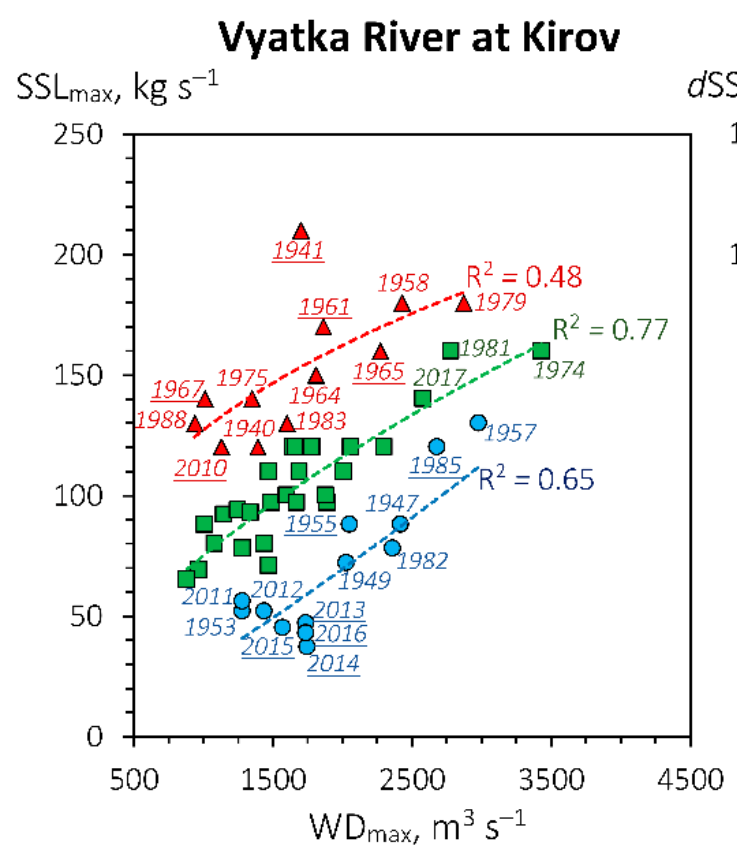

Vyatka River at Vyatskiye Polyany

$d S S L_{\max }, \mathrm{kg} \mathrm{s}^{-1}$

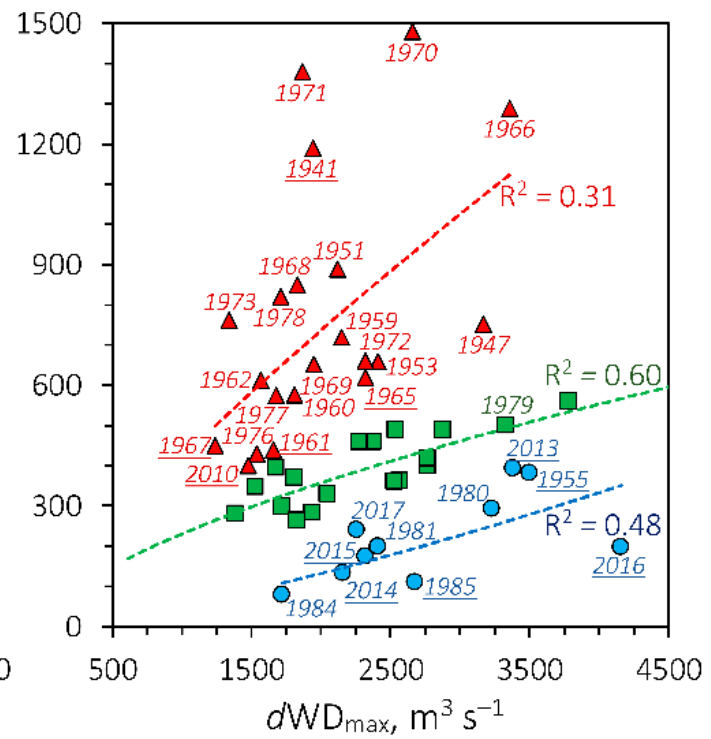

Figure 7. The ratio between maximum average monthly water discharge $\left(\mathrm{WD}_{\max }\right)$ and suspended sediment load $\left(\mathrm{SSL}_{\mathrm{max}}\right)$ of the Vyatka River. $\mathrm{R}^{2}$ — the coefficient of determination of a power trend (the dashed line). $d \mathrm{WD}_{\max }\left(d S S L_{\max }\right)$ - differentiated $\mathrm{WD}_{\max }\left(\mathrm{SSL}_{\max }\right)$.

In recent decades, the Vyatka River had a statistically significant increase in the minimum average monthly WD. It was the greatest in the river's lower course, primarily due to the rise in differentiated minimum average monthly discharge in the sub-basin between Vyatskiye Polyany and Kirov (Figure 8A).

It is also noteworthy that in periods with the highest values of the minimum average monthly WD, those values occurred, as a rule, in March, i.e., just before the beginning of snowmelt-induced floods. During periods of the lowest values of the minimum average monthly $\mathrm{WD}$, those values were observed in a more comprehensive intra-annual range (Figure 8B). In recent decades, this pattern has been violated in the lower Vyatka River. All this requires a further separate study. In general, the river's water flow during the warm season after the spring (snowmelt-induced) flood period has also increased statistically significantly in recent decades (Figure 8C).

All the noted changes in WD have reduced the amplitude of its intra-annual distribution in recent decades (Figure 9). This was somewhat more noticeable in the lower course of the river.

\subsection{Climate Change}

Over the past decades, the Vyatka River basin has experienced an increase in both air temperature and precipitation. As shown in Tables A1 and A2 (see Appendix B), only increases in mean annual temperature and annual rainfall were statistically significant. An increase in air temperature in spring, during the period of snow melting and forming snowmelt-induced floodwater flow of rivers in the basin, as well as an increase in precipitation during the warm season, the period of liquid precipitation (including erosionhazardous rainstorms), did not have statistical significance for any analyzed meteorological stations. The minimum increase in rainfall, especially during the warm season, was observed in the southwestern part of the Vyatka River basin, and the maximum increase was observed in the east and northeast of the basin (Figure 10). 


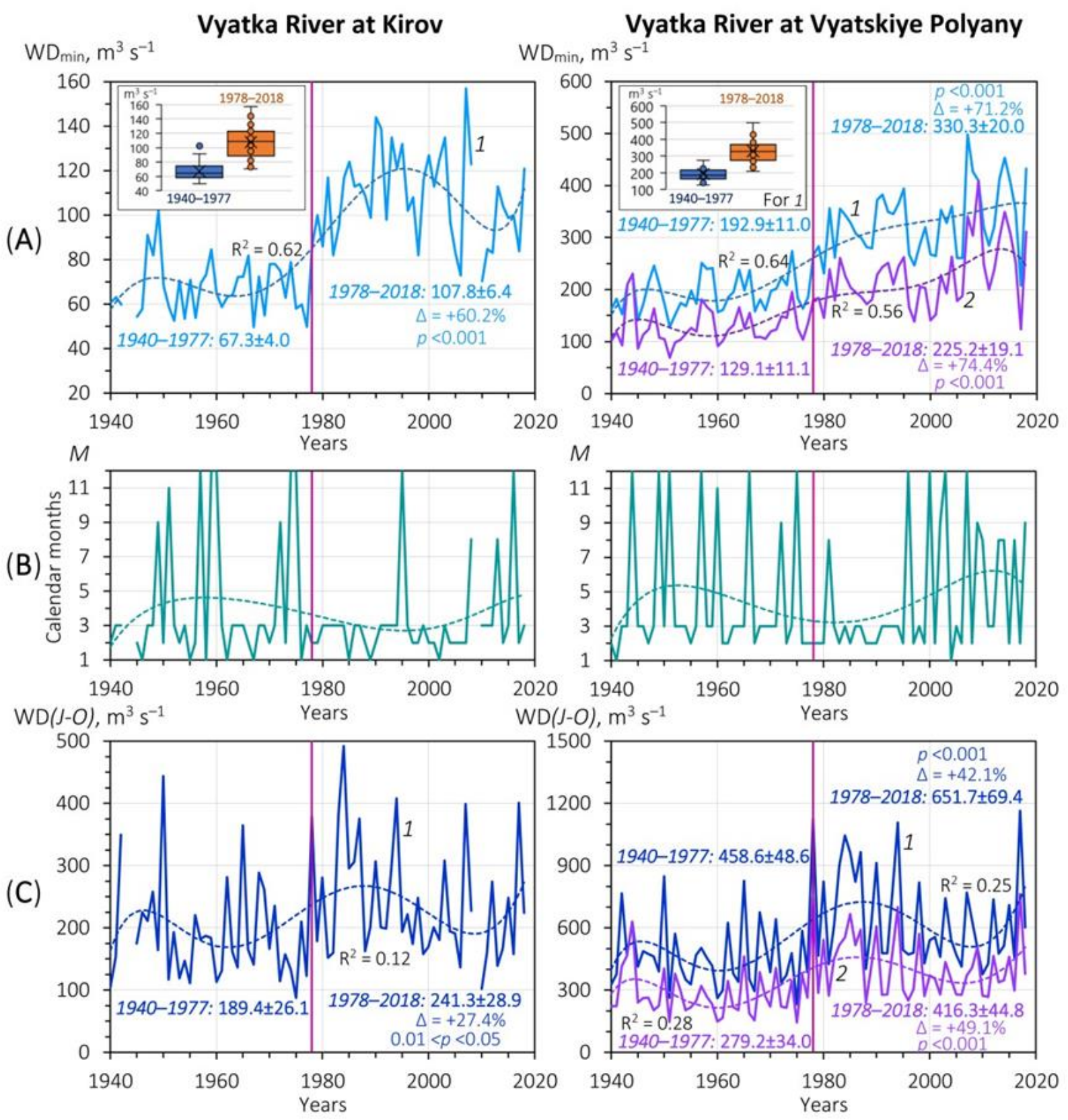

Figure 8. Changes in some characteristics of the Vyatka River's warm-season water discharge from 1940 to 2018. (A) - minimum average monthly water discharge $\left(\mathrm{WD}_{\min }\right)$; $(\mathbf{B})$ - the calendar month $(M)$ with $\mathrm{WD}_{\text {min }}$ ( (C) - average water discharge from July to October-WD(J-O); 1-observed water discharge at the hydrological stations, 2-differentiated water discharge, i.e., the difference between the discharge at Vyatskiye Polyany and Kirov; $\Delta$-relative change; $\mathrm{R}^{2}$ — the coefficient of determination of a sixth-degree polynomial trend (the dashed line). NB: After 1977, the most significant changes in $\mathrm{WD}_{\text {min }}$ occurred.

It is noteworthy that it was in the southwest of the basin that the increase in the mean annual air temperature in recent decades was the highest (see Figure 10). We also note relatively slight warming in the north half of the Vyatka River basin. The "tongue" of this warming, highlighted on the map as an isoline $+1^{\circ} \mathrm{C}$, penetrated far enough to the southeast within the comparatively high Upper Kama Upland. This upland was most likely also the cause of a greater increase in annual precipitation (see isoline $+15 \%$ in Figure 10 ), possibly due to precipitation of the cold season. This issue requires a separate study. 


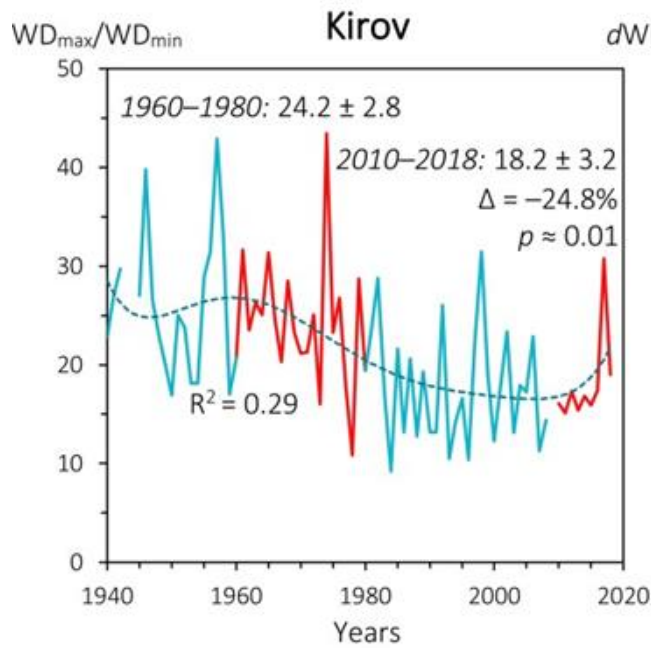

$d W D_{\max } / d W D_{\min }$ Vyatskiye Polyany

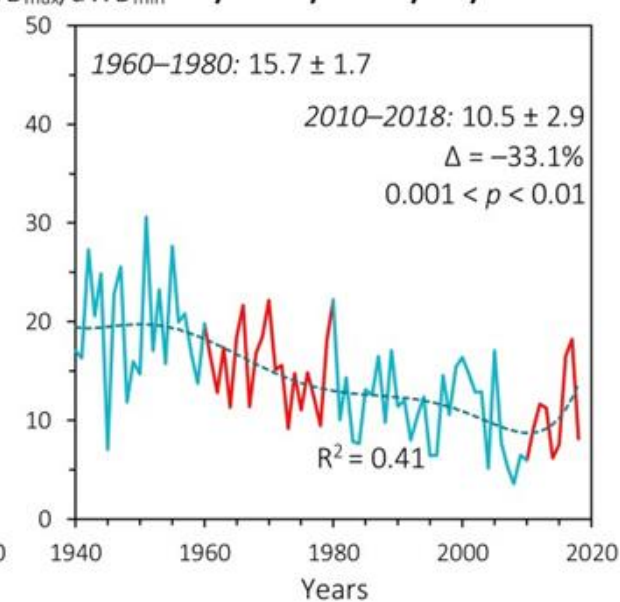

Figure 9. Changes in the ratio between $W D_{\max }$ and $W D_{\min }$ of the Vyatka River from 1940 to 2018. The average monthly water discharge: $W D_{\max }\left(d W D_{\max }\right)$-maximum (differentiated maximum), $W D_{\min }\left(d W D_{\min }\right)$ - minimum (differentiated minimum). $\Delta$-relative change; $\mathrm{R}^{2}$ — the coefficient of determination of a sixth-degree polynomial trend (the dashed line).

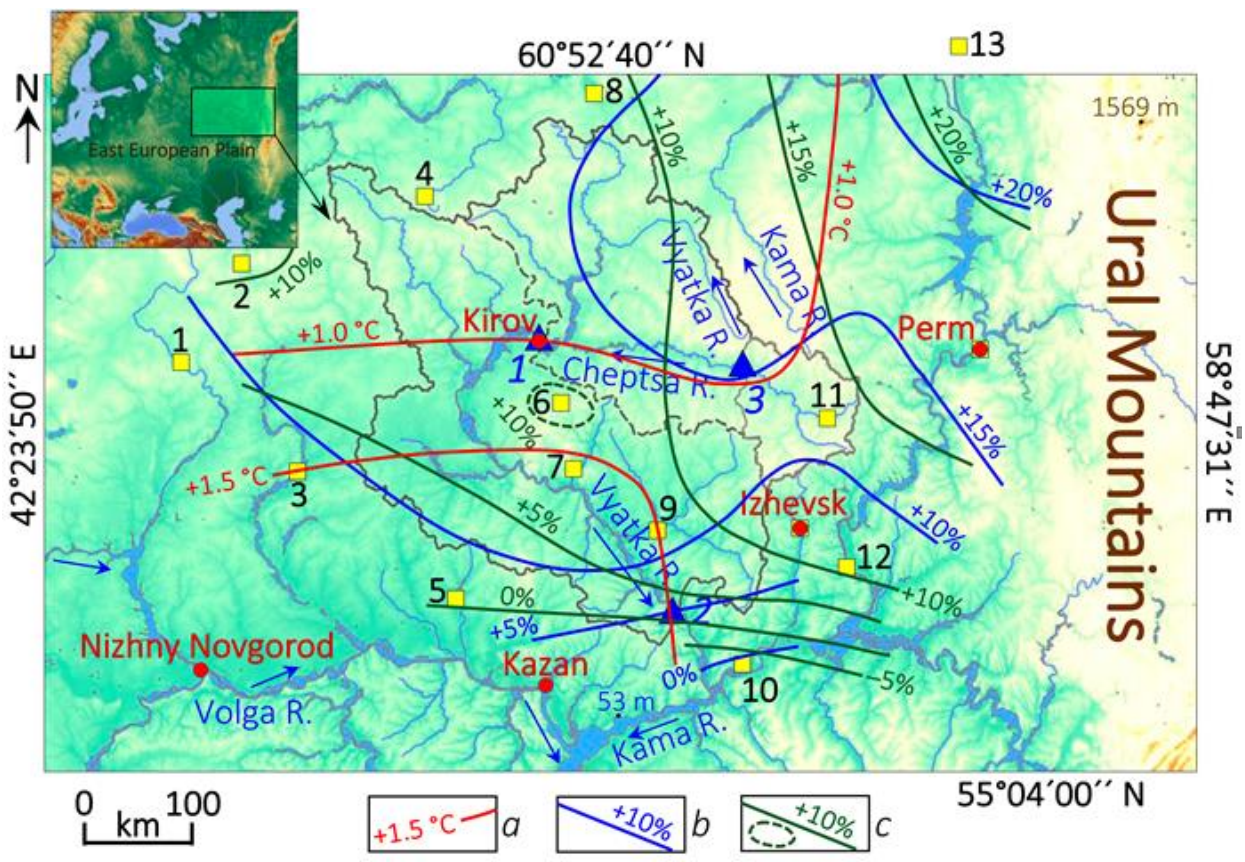

Figure 10. Changes in air temperature and precipitation within the Vyatka River basin and its surroundings. a-absolute changes in average annual air temperature between 1960-1980 and 2010-2019; $b(c)$ - relative changes in annual (warm-season) precipitation between 1966-1980 and 2010-2019. NB: The map is based on the data from Appendix B, Tables A1 and A2. For other symbols, see Figure 1.

The runoff coefficient calculated for the two analyzed sub-basins in the Vyatka River basin demonstrates statistically insignificant changes between 1966-1980 and 2010-2018 (Figure 11). It is noted that after the collapse of the USSR in 1991, the rhythmic changes in the runoff coefficient in the sub-basin upstream of Kirov began to lag somewhat in time compared to the sub-basin located downstream (see Figure 11). 

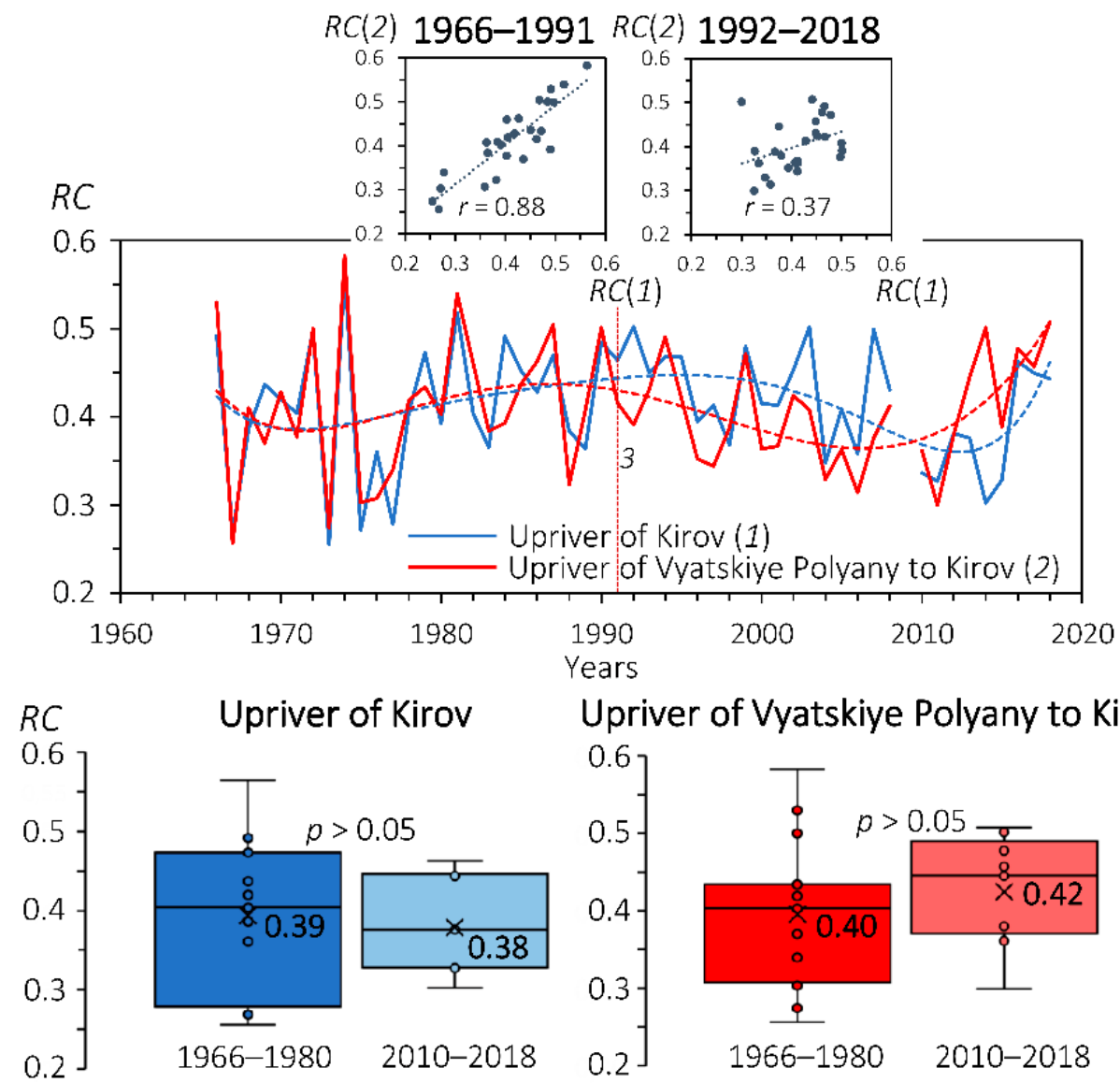

Upriver of Vyatskiye Polyany to Kirov

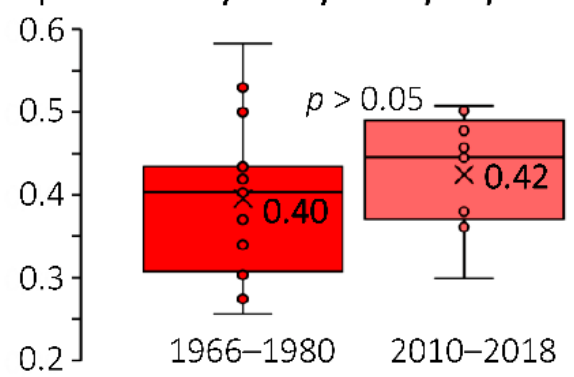

Figure 11. Changes in the annual runoff coefficient $(R C)$ within the Vyatka River basin from 1966 to 2018. $R C(1)$ - upriver of Kirov, $R C(2)$ - upriver of Vyatskiye Polyany to Kirov; 3-the time border between the RSFSR (the Russian Soviet Federative Socialist Republic as the main republic of the former USSR) and the Russian Federation; $r$ - the coefficient of linear correlation; the dashed line-a sixth-degree polynomial trend. Note: To calculate $R C$ for the sub-basin upriver of Kirov, annual precipitation was averaged over meteorological stations in Kirov, Oparino, Koigorodok, and Debessy (see Figure 1); for the sub-basin upriver of Vyatskiye Polyany to Kirov, annual precipitation was averaged over meteorological stations in Kirov, Oparino, Kumiony, Kilmez', Vetluga, and Yoshkar Ola (see Figure 1).

Since the mid-1960s, there have been no statistically significant trends in water storage in the snow (snow water equivalent) in the first ten days of April for three of the four meteorological stations (Figure 12A, see Figure 1) in the study region. In the town of Nolinsk, the water storage has increased statistically significantly in the last decade compared to the 1960s-1970s.

The presence of many gaps in the observation series associated with the lack of data makes it difficult to identify general trends in changes in the depth of soil freezing during snow melting and the formation of snowmelt-induced runoff in the study region. Nevertheless, we note the predominance of positive soil temperatures (at least in the topsoil) in the period under study, especially in the 1970s-2000s (Figure 12B).

\subsection{Land-Use/-Cover Changes}

In the Kirov Oblast and the Udmurt Republic, the administrative regions of European Russia, where the predominant part of the studied basin of the Vyatka River is located (see Figure 1), a reduction in cultivated land has been observed in recent decades. The most significant reduction took place in the Kirov Oblast, where cultivated land used to occupy and still occupies a relatively small area due to the features of the environment 
(Figure 13A). In total, in these two regions, cultivated land area decreased statistically significantly by $47 \%$ between $1960-1987$ and $2010-2018$. This decrease was mainly due to a reduced cultivated land area under grain crops (Figure 13B). In addition, the area under perennial and annual crops has decreased in the Kirov Oblast, while in the Udmurt Republic, these crops have increased (Figure 13C,D).
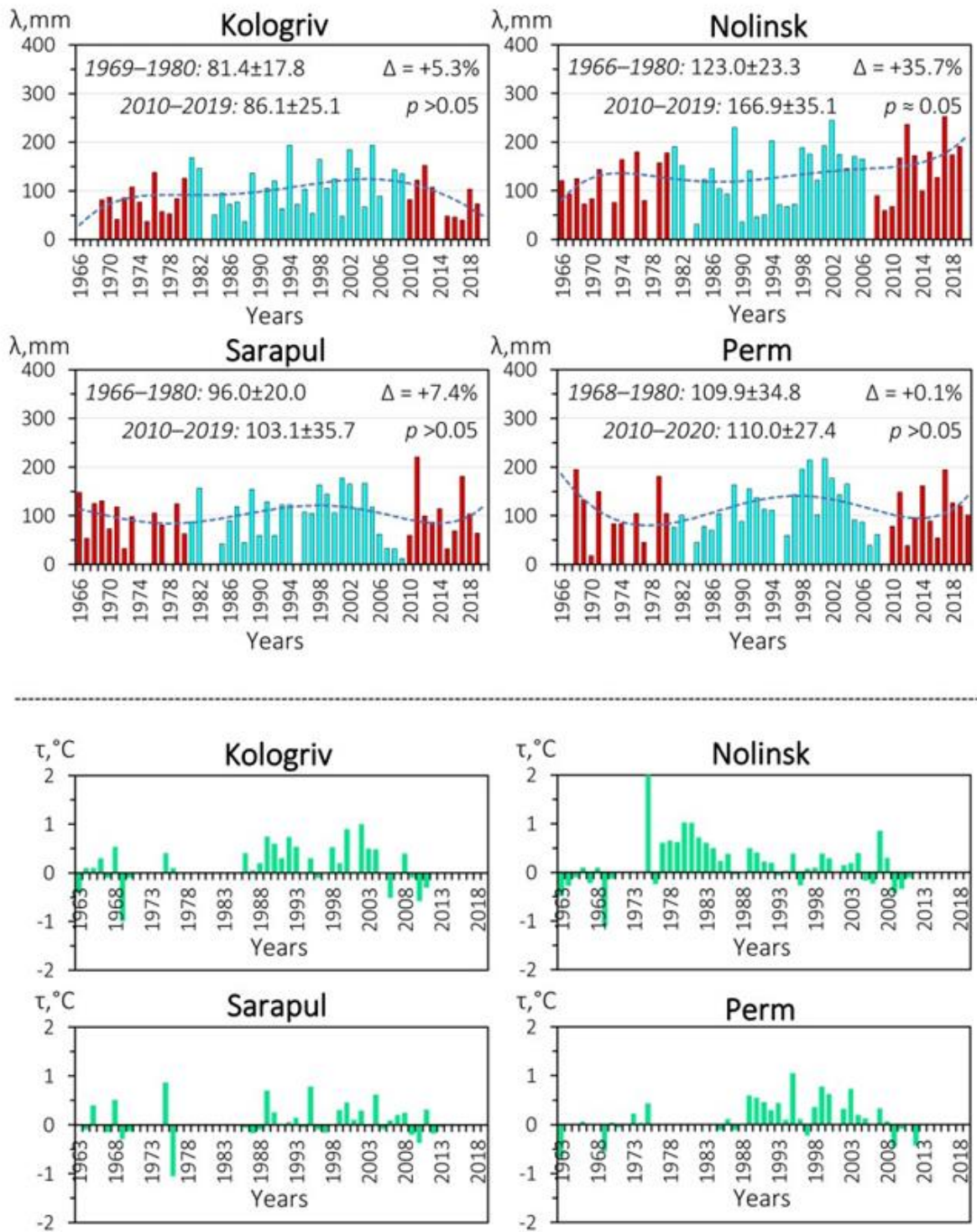

Figure 12. Contemporary changes in (A) water storage in the snow ( $\lambda$, snow water equivalent) and (B) soil temperature $(\tau$, at a depth of $20 \mathrm{~cm}$ ) in the first ten days of April at some analyzed meteorological stations in the Vyatka River basin and its surroundings (see Figure 1). $\Delta$-relative change; the dashed line-a fifth-degree polynomial trend.

The above crops in the periods under consideration occupied about $85-90 \%$ of the cultivated land of these two regions. Hence, the crop management factor ( $C$-factor) changes were calculated as representative for the studied river basin. Table 3 shows a significant decline in this factor between 1960-1987 and 2010-2018.

Along with reducing cultivated land, there was also a decrease in agricultural machinery on the regions' cropland. Unfortunately, we did not have data for the second half of the 1970s and the 1980s. Nevertheless, a considerable decline in agricultural machinery from the last year of the USSR to recent years was one of the consequences of the economic reform in post-Soviet Russia in the regions under consideration. Considering these changes 
and changes in the area of cultivated land, agricultural machinery per unit of cropland has also been significantly (almost three times or more) reduced (Figure 14).
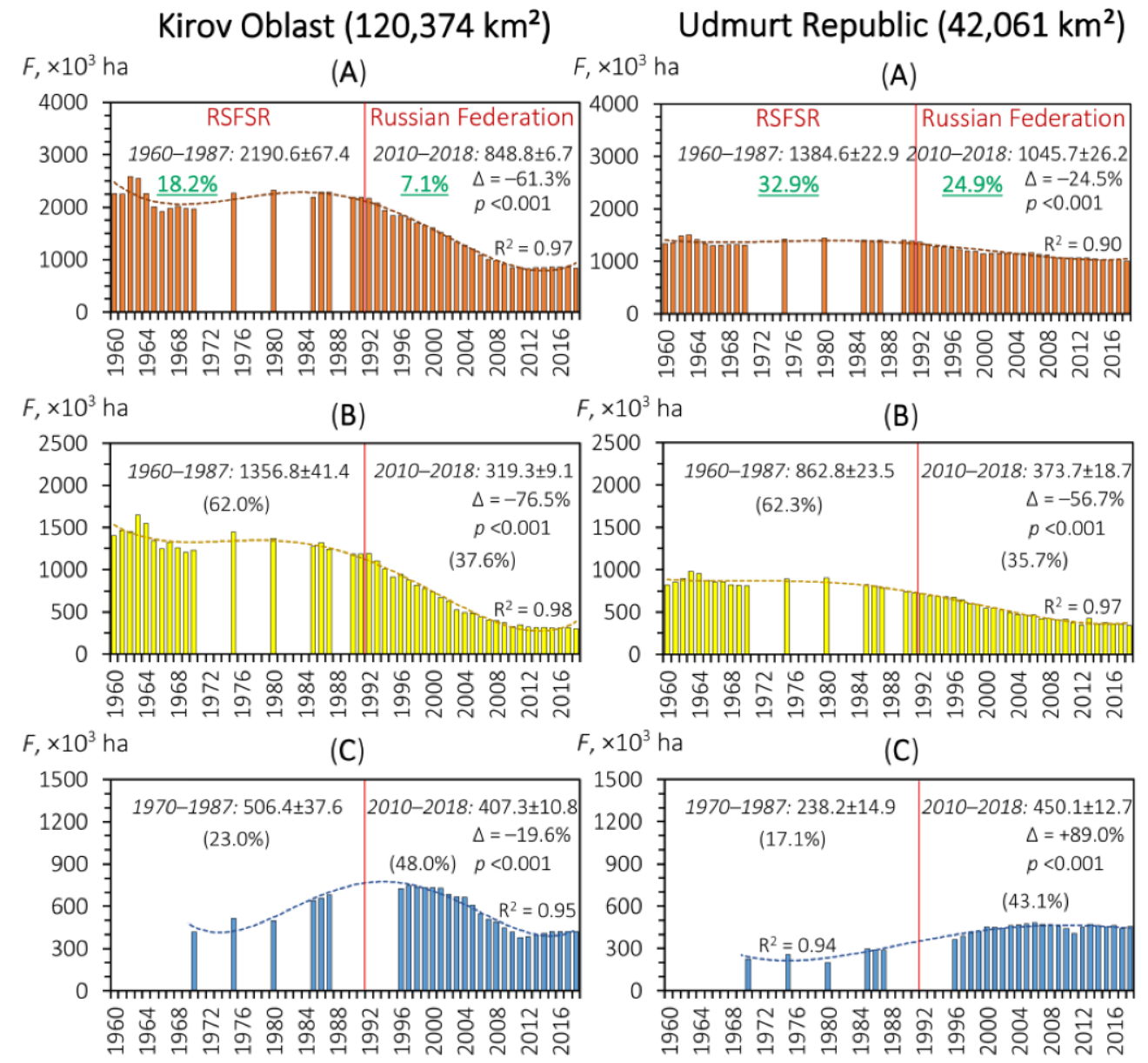

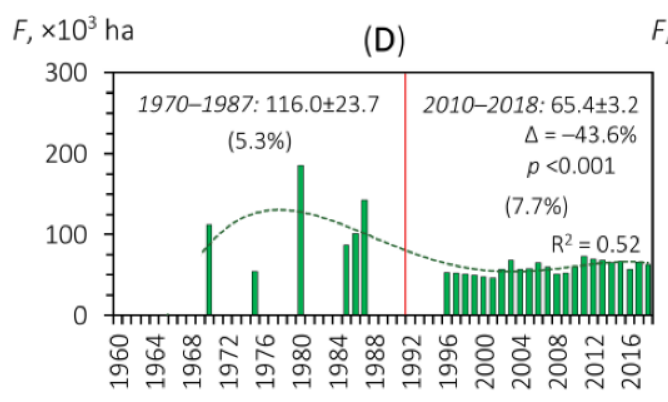

Years
$F, \times 10^{3}$ ha

(D)

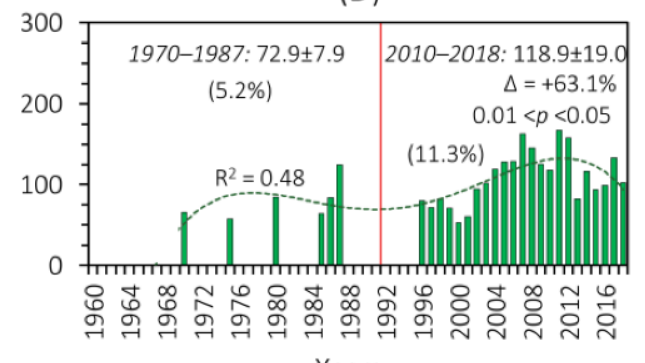

Figure 13. Changes in cultivated land area $(F)$ in the Kirov Oblast and the Udmurt Republic (see Figure 1) from 1960 to 2018. (A)—the total area of cultivated land; (B)—cereals; (C)—perennial crops; (D)—annual crops; $\Delta$-relative change; $\mathrm{R}^{2}$-the coefficient of determination of a fourth-degree polynomial trend (the dashed line). The underlined percentage in green is the share of cultivated land in the total area of the corresponding administrative region. The percentage in parentheses is the corresponding crop's share of the region's total cultivated land area. For other symbols, see Figure 11. 
Table 3. Integrated crop management factor $(\Sigma C)$ changes in the Kirov Oblast and the Udmurt Republic (see Figure 1) between 1960-1987 and 2010-2018.

\begin{tabular}{cccc}
\hline \multirow{2}{*}{ Monitoring Period } & \multicolumn{2}{c}{ Administrative Region } & \multirow{2}{*}{ In Total } \\
\cline { 2 - 3 } & Kirov Oblast & Udmurt Republic & \\
\hline $1960-1987$ & 0.36 & 0.39 & $0.37^{1}$ \\
$2010-2018$ & $0.11^{2}(0.24)^{3}$ & $0.21^{2}(0.26)^{3}$ & $0.17^{2}$ \\
$\Delta, \%$ & $-69.4^{2}(-33.3)^{3}$ & $-46.2^{2}(-33.3)^{3}$ & $-54.1^{2}$ \\
\hline
\end{tabular}

$\Delta$-relative change; ${ }^{1}$ weighted average by the total area of cropland; ${ }^{2}$ within arable (cultivated + abandoned) land; ${ }^{3}$ within cultivated land.

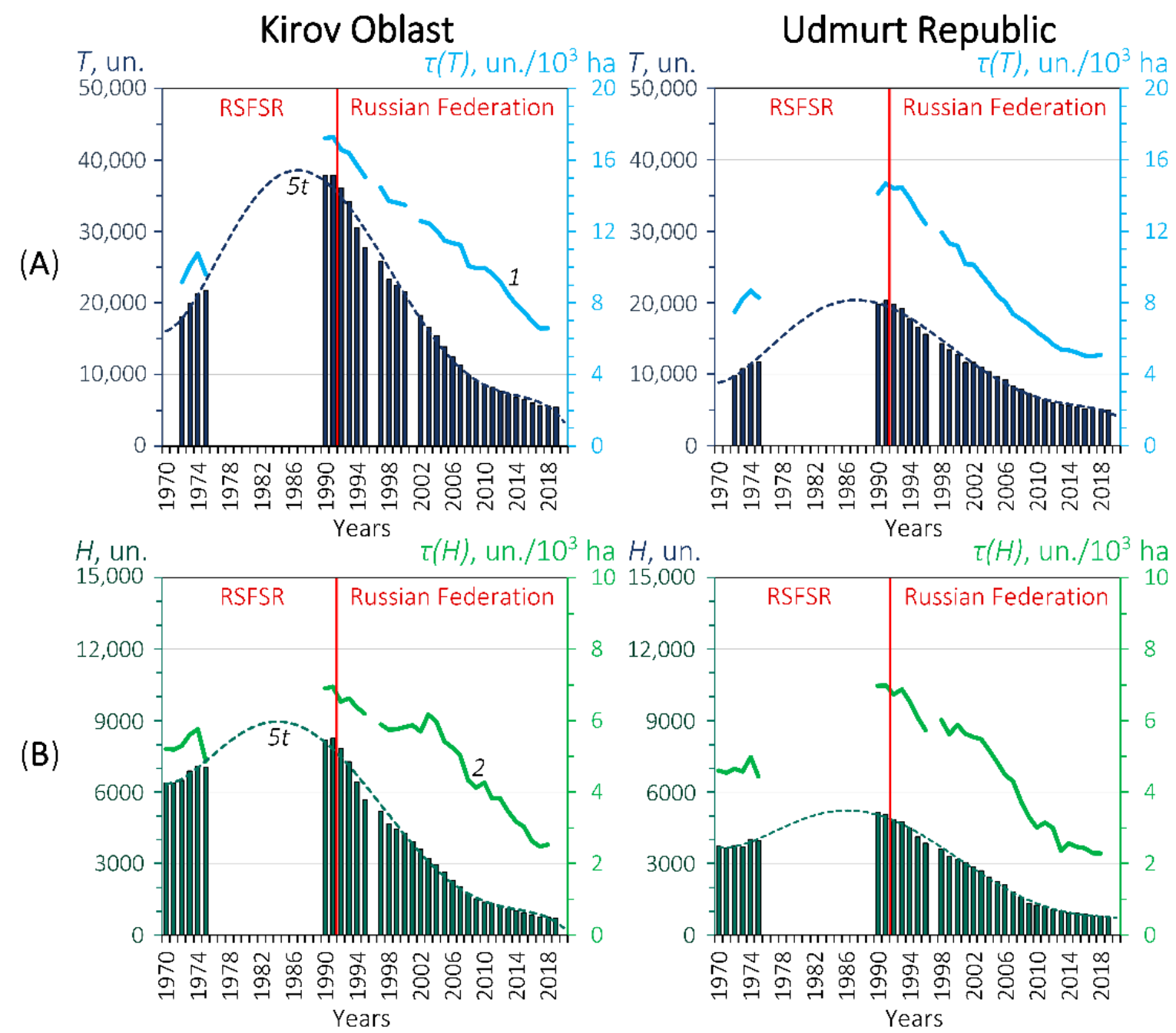

Figure 14. Changes in the amount of agricultural tractors $(\mathbf{A}, T)$ and grain combine harvesters $(\mathbf{B}, H)$ in the Kirov Oblast and the Udmurt Republic (see Figure 1) from 1970 to 2019. $\tau(T)$ and $\tau(H)$ are the amount of the tractors (1) and harvesters (2), respectively, per unit of cultivated land area. For other symbols, see Figure 11. The dashed line is a fifth-degree polynomial trend.

During the economic reform period in the administrative regions, there were multiple reductions in livestock (Figure 15). This circumstance, therefore, resulted in a decrease in livestock grazing on pastures. The total load of livestock per unit of pasture area has reduced, considering the expansion of ranges due to abandoned cropland. 


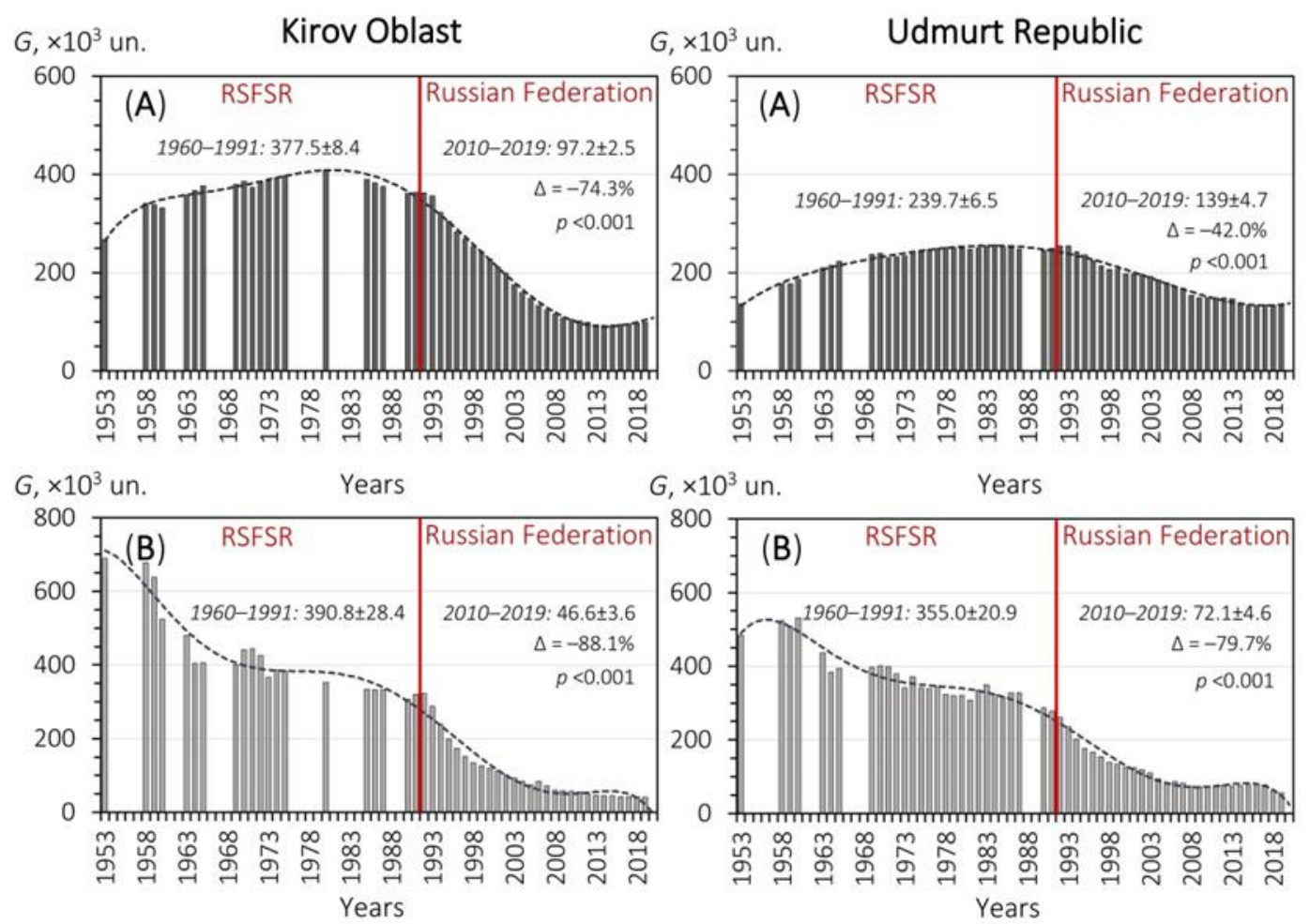

Figure 15. Changes in the amount $(G)$ of cattle (A) and goats and sheep (B) in the Kirov Oblast and the Udmurt Republic (see Figure 1) from 1953 to 2019. $\Delta$-relative change; the dashed line is a sixth-degree polynomial trend. For other symbols, see Figure 11.

\section{Discussion}

As shown earlier, within the past 100 years, the last 40 years in the Vyatka River basin were distinguished by the highest (average) annual air temperature and precipitation, as well as the highest water flow (see Figures 2 and 3). Against the background of these intra-secular changes, there has been a considerable reduction in SSL in recent decades (see Figure 5). This reduction was primarily associated with depressed erosion processes (mainly soil/gully erosion) in the river basin. What were the most likely driving factors for this reduction?

\subsection{Hydro-Climatic Changes as a Driving Factor}

The spring (snowmelt-induced) surface water runoff is traditionally considered by hydrologists as the leading contributor to the annual water flow and SSL of rivers in most of the East European Plain. In the last decade, its share has decreased, especially in the central and southern (forest-steppe and steppe) regions of the plain, due to global warming $[9,11,14]$. However, this runoff not only did not decrease but even increased (by $1-22 \%$ ) in recent decades in the Vyatka River basin, although without statistical significance. This increase was especially noticeable in the western and southern parts of the basin, between the analyzed stations in Kirov and Vyatskiye Polyany (see Figure 6). Most likely, this increase was due to a combination of a statistically insignificant increase in water storage in the snow and spring temperatures, chiefly in the western and southern sectors of the river basin. In the south part of the Vyatka River basin, which is the most agriculturally developed area, cropland (particularly unsown) contributes to faster meltwater delivery to the rivers, minimizing the water loss for evaporation. Moreover, snow melts faster on cropland than in forests. These processes ultimately resulted in a more significant increase in the spring surface water runoff in the lower sub-basin. At the same time, spring (snowmelt-induced) specific SSL (SSY) declined significantly (by 40-58\%) in the river basin between 1960-1980 and 2010-2018. Consequently, the noted long-term dynamics of spring 
surface water runoff cannot be considered the reason for the current decrease in sediment load in the Vyatka River basin. This runoff could increase the intensity of soil-gully erosion on agricultural fields and SSL of the basin's rivers but in no way reduce them.

There was a general increase in precipitation in the Vyatka River basin during the warm season (see Figure 10), but it was not statistically significant. We assume that this increase caused the general statistically significant rise in the river's WD (as a result of an increase in rainfall-induced surface water runoff) after the snowmelt-induced flood period, as shown in Figure 8. It is noteworthy that this increase was also greatest again in the sub-basin downriver of Kirov. It was proved that the frequency and intensity of heavy rains in Russia as a whole has risen sharply over the past half-century, increasing by $1-2 \%$ every ten years [50]. Consequently, the rise in rainfall-induced surface runoff, especially shower-induced runoff, could also lead to increased soil erosion intensity in the basin's interfluves, mainly on erosion-vulnerable cropland and grassland. An increase in SSL due to riverbed deformations because of increased water flow at this time of the year could also be quite probable. Unfortunately, we did not have data on river-erosion-induced sediment load during the warm season to confirm this assumption. However, we can confidently state that the increased precipitation of the warm season was also not the reason for the aforementioned considerable reduction in the annual SSL of the Vyatka River.

\subsection{Land-Use/Cover Changes as a Driving Factor}

A reduction in cultivated land and a change in the structure of the sowing fund for the remaining cropland were among the main reasons for the decrease in sediment load and the overall intensity of soil/gully erosion in the Vyatka River basin. On the one hand, the total reduction of cultivated land by almost half, or $16,807 \mathrm{~km}^{2}$, mainly in the Kirov Oblast and the Udmurt Republic, resulted in a proportional increase in abandoned land, which over time was overgrown with herbaceous and partly woody zonal vegetation (see Appendix C, Figure A4). Sod cover and forest (mainly coniferous) litter on abandoned lands reliably protect the soil against any type of erosion. On the other hand, the share of relatively erosion-hazardous grain crops has significantly decreased within the remaining cultivated land; in contrast, the share of perennial grasses characterized by high antierosion properties has increased (see Figure 13). The latter could substantially affect the immobilization of sediments. For instance, erosional denudation of soil material under perennial grasses was, on average, about 50 times less than on cultivated land, according to earlier studies by I.A. Kuznik in 1961 [51] in the forest-steppe of the Trans-Volga region of European Russia.

On the cropland remaining after the abandonment, the amount of heavy agricultural machinery, primarily tractors and combine harvesters, was also considerably reduced, which most likely resulted in a decrease in the overall mechanical load (pressure) on the soil (its compaction, especially the subsoil). These processes could improve the water filtration properties of cultivated soils and, consequently, bring about an additional reduction in soil erosion risk.

There was a noticeable decline in livestock in the Kirov Oblast and the Udmurt Republic, primarily due to the redistribution of livestock between state and private farms and decreased rural population [52]. From 1960-1990 to 2010-2019, the total number of cattle decreased in these two administrative regions by $61 \%$, sheep and goats-by $84.5 \%$. The latter means a reduction in mechanical compaction of the topsoil $[53,54]$ and a lower load on the vegetation cover within the old and recently formed (after abandoning cultivated land) pastures. Consequently, such pasture soils are less susceptible to soil and gully erosion, and they are much less likely to serve as sources of sediment supplied to the river network of the Vyatka River basin.

Since the most significant decrease in SSL occurred in the sub-basin of the Vyatka River between Kirov and Vyatskiye Polyany (see Figure 6), we assume that it was in this part of the river basin (especially in its relatively better agriculturally developed southwestern and southern sectors) that the above land-use/-cover changes were most significant. Moreover, 
this decrease in SSL could have been greater, especially in the sub-basin downriver of Kirov, if it were not for the aforementioned likely intensification of soil erosion and riverbed erosion and increase in sediment load due to increased snowmelt-induced and particularly rainfall-induced surface runoff (river WD). It is also assumed that the discrepancy in the relative synchronicity of the runoff coefficient in the two main sub-basins after 1991 (see Figure 11) was related to the noted anthropogenic changes in the Vyatka River basin. This issue requires a separate study.

The above is a generalized view of hydrological and erosional changes and their causes in the studied Vyatka River basin. Obviously, in sub-basins smaller than those analyzed, the obtained regularities can vary depending on the characteristics of the environment. For example, in the Cheptsa River sub-basin upriver of Glazov (see Figure 1), there has been a more significant reduction in SSL in recent years (see Appendix C, Figure A5) than in the entire Vyatka River sub-basin upriver of Kirov (see Figure 5), of which it is a part. This happened even though the relative decline in cropland area in the Cheptsa River sub-basin was close to or even smaller than that in the Vyatka River sub-basin. One of the main reasons for this is the difference in the sub-basins' elevation: the average elevation of the Vyatka River sub-basin upstream of Kirov is $183 \mathrm{~m}$, whereas the sub-basin of the Cheptsa River upriver of Glazov averages $209 \mathrm{~m}$ (this sub-basin occupies the southern part of the Upper Kama Upland; see Figure 1). In the conditions of well-moistened landscapes in the south of the forest zone of the plain, apparently, even small changes in surface gradients and the density of the hollow and small-dry-valley dissection of the relief can cause noticeable changes in the rate of soil erosion and the delivery of sediment to the river network when changing land use/cover. This was especially true in recent decades, with the noted rise in shower-induced surface runoff in the year's warm season.

\subsection{Other Evidence of the Decrease in the Rate of Erosion in the Vyatka River Basin}

The results of erosion modeling carried out by the research team of Lomonosov Moscow State University [22] confirm a significant reduction in soil erosion intensity in the study region. According to these results, soil erosion rates declined between 1980 and 2012-2014 by 52\% in the Kirov Oblast and 51\% in the Udmurt Republic. Notably, the total relative soil loss between the years indicated was modeled in these regions as $85 \%$ and $63 \%$, respectively. This trend coincided well with a decrease in gully head-cuts retreat rates within plowed catchments in the Udmurt Republic over the past 40 years: from $1.3 \mathrm{~m} \mathrm{y}^{-1}$ in 1978-1997 to $0.3 \mathrm{~m} \mathrm{y}^{-1}$ in 1998-2014, i.e., by 77\% [23]. We [55] also found a commensurately significant decrease in the rate of accumulation of washed-out soil in one of the small and almost wholly cultivated dry-valley catchments of the Udmurt Republic, located in the Izh River basin (see Figure 1), which adjoins the Vyatka River basin from its southeast. So, in 1954-1986, the washed-out soil material accumulation rates in the dry-valley bottom of this catchment ranged from 1.8 to $2.5 \mathrm{~cm} \mathrm{y}^{-1}$, while in 1987-2016, they ranged from 0.15 to $0.75 \mathrm{~cm} \mathrm{y}^{-1}$, i.e., decreased by at least $2.5-3.0$ times.

\subsection{Comparison with Neighboring Regions}

A few studies, carried out mainly in the southern half of European Russia, have shown an almost universal decrease in erosion intensity and river SSL [21,56-59]. This decrease was most significant in the forest-steppe zone of the East European Plain [21], especially in the Middle Volga region [14] located south of the Vyatka River basin. However, in contrast to the Vyatka River basin, the decrease in erosion intensity and river SSL in the river basins of the more southern regions of European Russia occurred with considerable or predominant participation of climate [21,60].

\subsection{Limitations and Uncertainties of the Study}

1. Estimates of the rates and causes of contemporary trends in erosion intensity obtained based on river SSL data give only a general idea of the entire Vyatka River basin. 
It is evident that these rates and causes may vary at local levels depending on the environment and human activities.

2. The analysis of long-term changes in SSL is one of the most reliable methods to identify the general trends in erosion intensity in the Vyatka River basin. However, the findings require verification using independent approaches and methods, primarily field research, GIS technologies within agricultural land with an increased risk of erosion [61], modeling of soil loss tolerance [62], etc.

3. Although river suspended sediment formed by soil/gully erosion on watersheds plays a dominant role (especially in plowed river basins) in forming the annual SSL $[36,44,63]$, the contribution of sediment created by riverbed deformation to the above trends in the Vyatka River is still not clear.

4. We did not consider the possible impact of reservoirs and ponds on long-term changes in river SSL. However, we note that most of them were created in the river basin during the late Soviet Union. The creation of new artificial water bodies in recent decades has been minimal. It was not facilitated by the general degradation of industry and agriculture in the country, especially in the Kirov Oblast, where the main part of the Vyatka River basin is located.

5. We also left out of consideration the impact of erosion control measures in the region in recent decades. They were predominantly local.

\section{Conclusions}

- During the past half-century, there has been a statistically insignificant increase in water flow in the Vyatka River basin. It was caused by a statistically insignificant increase in water flow during the spring (snowmelt-induced) flood and by a statistically significant rise in the flow during the year's warm and cold seasons. The most significant increase in the flow was found in the Vyatka River's sub-basin located downstream of Kirov (the west and primarily south parts of the river basin). The main reasons for the noted trends were increased precipitation, including summer heavy rainfall.

- In contrast to the noted changes in water flow, SSL and, consequently, overall erosion intensity in the Vyatka River basin have essentially and statistically significantly decreased over the past half-century (up to 48-58\% between 1960-1980 and 2010-2018). As in the case of water flow changes, more significant reductions occurred in the west and, especially, south of the river basin (the sub-basin located downriver of Kirov). The most probable reasons for these changes are a reduction in cultivated land area (by 47\% between 1960-1987 and 2010-2018), changes in the structure of sown areas towards the prevalence of crops with comparatively better anti-erosion characteristics, and a decline in the amount of both heavy agricultural machinery on cultivated fields and livestock in pastures, which reduced the load on the soil and, accordingly, its vulnerability to erosion processes.

- The study showed that reducing the intensity of overall erosion and SSL in the Vyatka River basin was part of the regional reduction of these processes, which covered the southern, most agriculturally developed part of the East European Plain. However, in contrast to the southern territories, in the south of the forest zone, at least in the east sector of the plain, the role of human activity in the reduction noted was dominant. This study contributes to the ongoing discussions on the absolute and relative roles of climate change in and direct anthropogenic impacts on detected changes in erosion and denudation processes.

Author Contributions: Conceptualization, A.V.G.; methodology, A.V.G.; software, A.V.G.; validation, A.V.G.; formal analysis, A.V.G. and A.G.S.; investigation, A.V.G.; resources, A.V.G. and A.G.S.; data curation, A.V.G.; writing — original draft preparation, A.V.G.; writing-review and editing, A.V.G. and A.A.B.; visualization, A.V.G.; supervision, A.V.G.; project administration, A.V.G.; funding acquisition, A.V.G. All authors have read and agreed to the published version of the manuscript. 
Funding: This paper has been supported by the Kazan Federal University Strategic Academic Leadership Program and was carried out within the framework of the intra-university grant of the Belgorod State University to support the creation and development of scientific departments as centers of excellence.

Institutional Review Board Statement: Not applicable.

Informed Consent Statement: Not applicable.

Data Availability Statement: Data used in the study are available from the published "The National Economy of the RSFSR" (https:/ / istmat.info/statistics (accessed on 7 May 2021)); "Agriculture of the USSR: Statistical Bulletin. Main indicators of crop production development" (http:/ /istmat.info/ node/26167 (accessed on 8 May 2021)); electronic statistical resources of the Russian Federation (https:/ / fedstat.ru (accessed on 10 May 2021)); the Federal State Statistics Service (http:/ /www. gks.ru (accessed on 10 May 2021)); The Automated Information System of State Monitoring for Water Bodies of the Federal Agency for Water Resources of the Ministry of Natural Resources and Environment of the Russian Federation (http:/ / gmvo.skniivh.ru (accessed on 15 May 2021)); and "Water Regime of the Rivers of European Russia" (http:/ / autolab.geogr.msu.ru/hydrograph/\#, accessed on 27 April 2021).

Acknowledgments: The authors thank four anonymous reviewers who comprehensively contributed to the manuscript, providing valuable reviews.

Conflicts of Interest: The authors declare no conflict of interest. The funders had no role in the design of the study; in the collection, analyses, or interpretation of data; in the writing of the manuscript; or in the decision to publish the results.

\section{Appendix A}

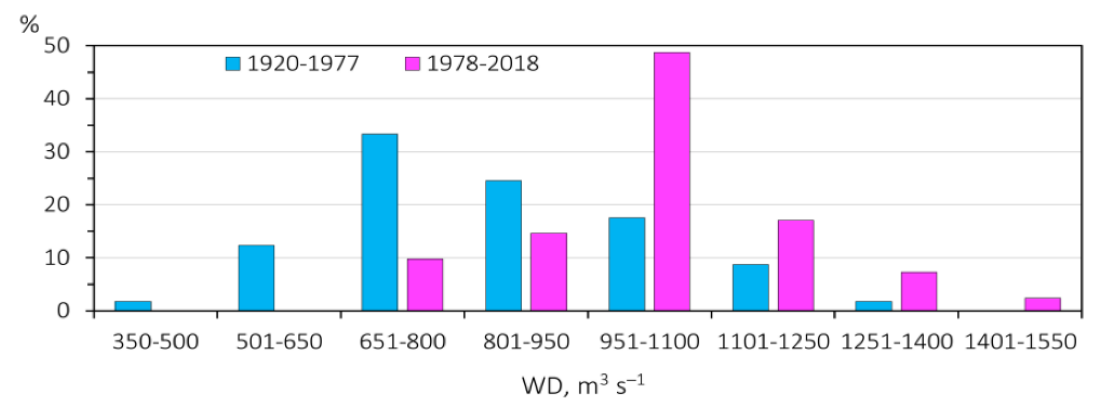

Figure A1. Changes in the relative distribution of the Vyatka River's average annual water discharge (WD) at Vyatskiye Polyany, the Kirov Oblast of European Russia (see Figure 1), between 1920-1977 and 1978-2018.

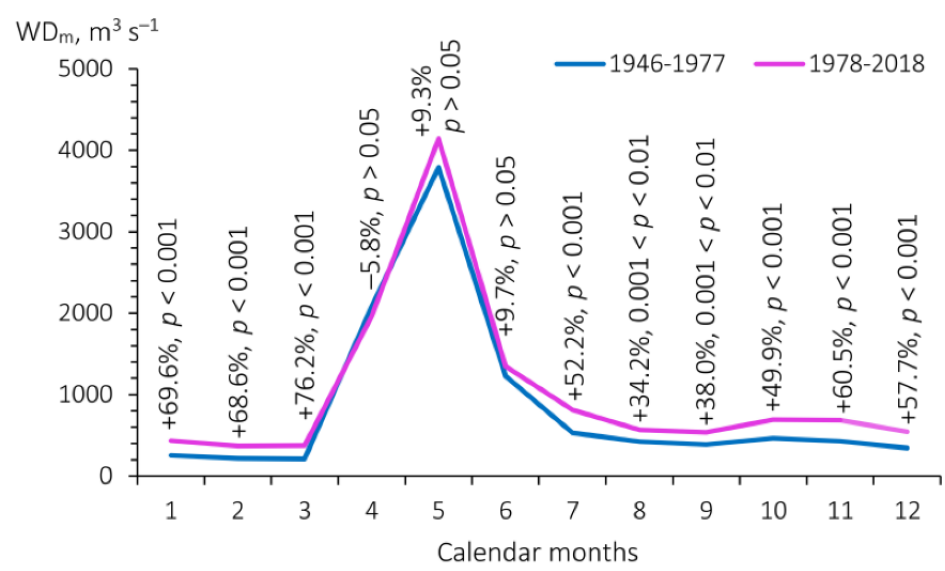

Figure A2. Changes in the Vyatka River's mean monthly water discharge ( $\left.\mathrm{WD}_{\mathrm{m}}\right)$ at Vyatskiye Polyany, the Kirov Oblast of European Russia (see Figure 1), between 1946-1977 and 1978-2018. $+69.6 \%,+68.6 \%$. . - relative changes in the discharge between the periods with probability $p$. 


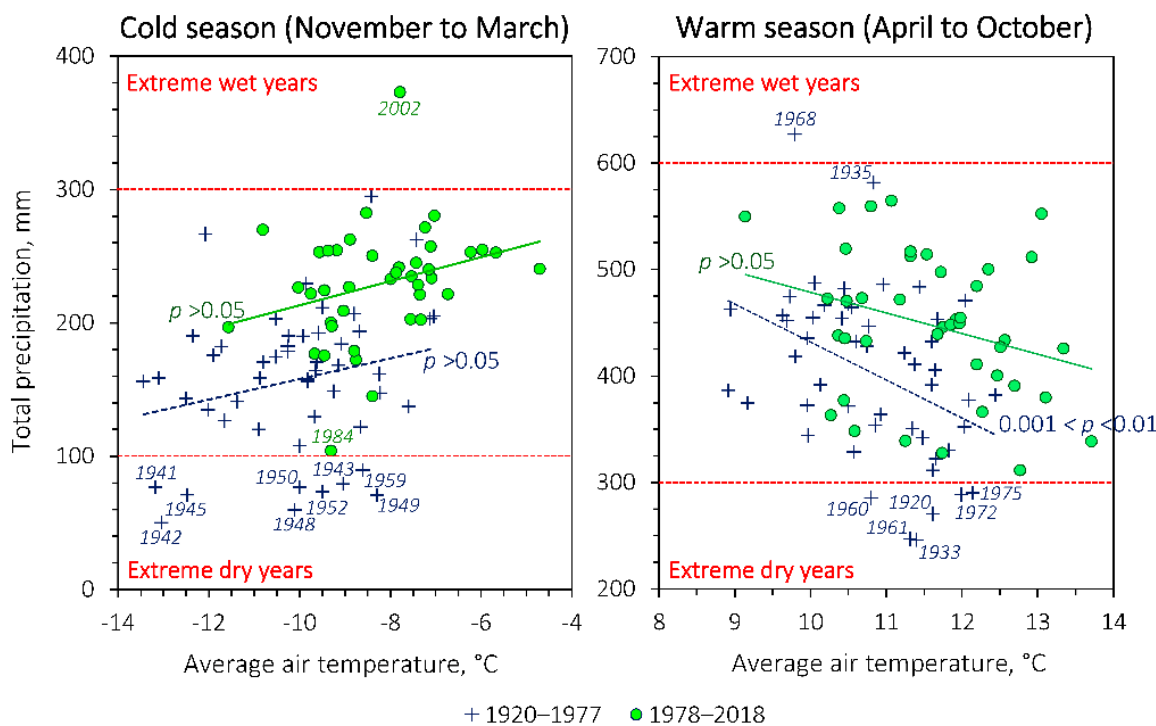

Figure A3. Changes in the ratio between the average air temperature and precipitation during the warm and cold seasons in Kirov (see Figure 1) from 1920-1977 to 1978-2018.

\section{Appendix B}

Table A1. Changes in air temperature $\left({ }^{\circ} \mathrm{C}\right)$ at the analyzed meteorological stations.

\begin{tabular}{|c|c|c|c|c|}
\hline \multirow{2}{*}{$\begin{array}{l}\text { Meteorological Station } \\
\text { (See Figure 1) }\end{array}$} & \multirow{2}{*}{ Temperature: } & \multicolumn{2}{|c|}{ Monitoring Period } & \multirow{2}{*}{$\Delta,{ }^{\circ} \mathrm{C}$} \\
\hline & & 1960-1980 & 2010-2019 & \\
\hline \multirow{3}{*}{ Oparino } & Mean annual & $1.1 \pm 0.5$ & $2.7 \pm 0.3$ & $+1.6^{* * *}$ \\
\hline & March & $-5.7 \pm 1.5$ & $-5.1 \pm 2.3$ & $+0.6 *$ \\
\hline & April & $2.1 \pm 1.0$ & $3.3 \pm 0.9$ & $+1.2 *$ \\
\hline \multirow{3}{*}{ Vetluga } & Mean annual & $2.6 \pm 0.4$ & $4.3 \pm 0.3$ & $+1.7^{* * *}$ \\
\hline & March & $-5.1 \pm 1.3$ & $-3.6 \pm 2.1$ & $+1.5 *$ \\
\hline & April & $3.6 \pm 1.0$ & $4.8 \pm 0.8$ & $+1.2 *$ \\
\hline \multirow{3}{*}{ Yoshkar Ola } & Mean annual & $2.8 \pm 0.5$ & $4.7 \pm 0.3$ & $+1.9^{* * *}$ \\
\hline & March & $-5.7 \pm 1.5$ & $-3.9 \pm 1.9$ & $+1.8 *$ \\
\hline & April & $4.1 \pm 1.2$ & $5.3 \pm 0.9$ & $+1.2 *$ \\
\hline \multirow{3}{*}{ Kirov } & Mean annual & $2.4 \pm 0.4$ & $3.5 \pm 0.6$ & $+1.1^{* * *}$ \\
\hline & March & $-5.4 \pm 1.4$ & $-4.4 \pm 2.0$ & $+1.0 *$ \\
\hline & April & $3.6 \pm 1.1$ & $4.5 \pm 1.1$ & $+0.9 *$ \\
\hline \multirow{3}{*}{ Kumiony } & Mean annual & $1.8 \pm 0.4$ & $3.4 \pm 0.3$ & $+1.6^{* * *}$ \\
\hline & March & $-6.2 \pm 1.5$ & $-4.8 \pm 2.0$ & $+1.4 *$ \\
\hline & April & $2.7 \pm 1.1$ & $4.0 \pm 1.1$ & $+1.3 *$ \\
\hline \multirow{3}{*}{ Koigorodok } & Mean annual & $0.6 \pm 0.5$ & $2.0 \pm 0.4$ & $+1.4^{* *}$ \\
\hline & March & $-6.7 \pm 1.8$ & $-6.1 \pm 2.6$ & $+0.6^{*}$ \\
\hline & April & $1.5 \pm 1.1$ & $2.7 \pm 1.0$ & $+1.2 *$ \\
\hline \multirow{3}{*}{ Kilmez' } & Mean annual & $2.5 \pm 0.4$ & $4.1 \pm 0.3$ & $+1.6^{* * *}$ \\
\hline & March & $-5.7 \pm 1.4$ & $-4.2 \pm 1.8$ & $+1.5 *$ \\
\hline & April & $3.7 \pm 1.2$ & $4.7 \pm 1.1$ & $+1.0 *$ \\
\hline \multirow{3}{*}{ Yelabuga } & Mean annual & $3.3 \pm 0.5$ & $4.9 \pm 0.4$ & $+1.6^{* * *}$ \\
\hline & March & $-5.5 \pm 1.5$ & $-4.1 \pm 1.8$ & +1.4 * \\
\hline & April & $4.6 \pm 1.2$ & $5.8 \pm 1.3$ & $+1.2^{*}$ \\
\hline
\end{tabular}


Table A1. Cont.

\begin{tabular}{ccccc}
\hline \multirow{2}{*}{$\begin{array}{c}\text { Meteorological Station } \\
\text { (See Figure 1) }\end{array}$} & Temperature: & \multicolumn{2}{c}{ Monitoring Period } & \multirow{2}{*}{$\mathbf{\Delta ,}{ }^{\circ} \mathbf{C}$} \\
\cline { 3 - 4 } & & $\mathbf{1 9 6 0 - 1 9 8 0}$ & $\mathbf{2 0 1 0 - 2 0 1 9}$ & \\
\hline \multirow{2}{*}{ Izhevsk } & Mean annual & $2.3 \pm 0.4$ & $3.6 \pm 0.3$ & $+1.3^{* * *}$ \\
& March & $-6.0 \pm 1.4$ & $-4.9 \pm 1.7$ & $+1.1^{*}$ \\
& April & $3.6 \pm 1.2$ & $4.2 \pm 1.2$ & $+0.6^{*}$ \\
\hline \multirow{2}{*}{ Debessy } & Mean annual & $1.3 \pm 0.4$ & $2.7 \pm 0.5$ & $+1.4^{* * *}$ \\
& March & $-6.8 \pm 1.6$ & $-5.7 \pm 1.9$ & $+1.1^{*}$ \\
& April & $2.4 \pm 1.1$ & $3.4 \pm 1.1$ & $+1.0^{*}$ \\
\hline \multirow{2}{*}{ Perm } & Mean annual & $1.7 \pm 0.4$ & $3.0 \pm 0.3$ & $+1.3^{* * *}$ \\
& March & $-5.7 \pm 1.5$ & $-4.4 \pm 1.9$ & $+1.3^{*}$ \\
& April & $3.3 \pm 1.1$ & $4.3 \pm 1.2$ & $+1.0^{*}$ \\
\hline \multirow{2}{*}{ Cherdyn' $^{*}$} & Mean annual & $0.0 \pm 0.5$ & $1.5 \pm 0.3$ & $+1.5^{* * *}$ \\
& March & $-7.0 \pm 1.6$ & $-5.8 \pm 2.2$ & $+1.2^{*}$ \\
& April & $1.1 \pm 1.1$ & $2.5 \pm 1.1$ & $+1.4^{*}$ \\
\hline
\end{tabular}

$\Delta$-changes between the periods. The statistical probability $p:^{*}>0.05,{ }^{* *} 0.001-0.01,{ }^{* * *}<0.001$.

Table A2. Changes in precipitation ( $\mathrm{mm}$ ) at the analyzed meteorological stations.

\begin{tabular}{|c|c|c|c|c|}
\hline \multirow{2}{*}{$\begin{array}{l}\text { Meteorological Station } \\
\text { (See Figure 1) }\end{array}$} & \multirow{2}{*}{ Precipitation } & \multicolumn{2}{|c|}{ Monitoring Period } & \multirow{2}{*}{$\Delta, \%$} \\
\hline & & 1966-1980 & 2010-2019 & \\
\hline Nikol'sk & $\begin{array}{c}\text { Annual } \\
\text { April-to-October }\end{array}$ & $\begin{array}{c}584.7 \pm 48.2 \\
406.5 \pm 42.4 \\
(69.5)\end{array}$ & $\begin{array}{c}671.0 \pm 56.8 \\
448.3 \pm 49.8 \\
(66.8)\end{array}$ & $\begin{array}{l}+14.8 * * \\
+10.3 *\end{array}$ \\
\hline Vetluga & $\begin{array}{c}\text { Annual } \\
\text { April-to-October }\end{array}$ & $\begin{array}{c}652.0 \pm 54.3 \\
448.8 \pm 51.2 \\
(68.8)\end{array}$ & $\begin{array}{c}696.2 \pm 48.8 \\
453.8 \pm 43.3 \\
(65.2)\end{array}$ & $\begin{array}{l}+6.8^{*} \\
+1.1^{*}\end{array}$ \\
\hline Oparino & $\begin{array}{c}\text { Annual } \\
\text { April-to-October }\end{array}$ & $\begin{array}{c}639.1 \pm 35.8 \\
448.4 \pm 29.0 \\
(70.2)\end{array}$ & $\begin{array}{c}713.6 \pm 88.0 \\
490.2 \pm 82.1 \\
(68.7)\end{array}$ & $\begin{array}{l}+11.7 * \\
+9.3 *\end{array}$ \\
\hline Yoshkar Ola & $\begin{array}{c}\text { Annual } \\
\text { April-to-October }\end{array}$ & $\begin{array}{c}554.8 \pm 56.1 \\
398.0 \pm 48.1 \\
(71.7)\end{array}$ & $\begin{array}{c}604.5 \pm 57.9 \\
399.3 \pm 51.6 \\
(66.1)\end{array}$ & $\begin{array}{l}+8.9 * \\
+0.3 *\end{array}$ \\
\hline Kirov & $\begin{array}{c}\text { Annual } \\
\text { April-to-October }\end{array}$ & $\begin{array}{c}593.7 \pm 47.5 \\
409.5 \pm 40.8 \\
(69.0)\end{array}$ & $\begin{array}{c}678.0 \pm 45.9 \\
434.7 \pm 49.4 \\
(64.1)\end{array}$ & $\begin{array}{l}+14.2 \text { ** } \\
+6.1 *\end{array}$ \\
\hline Kumiony & $\begin{array}{c}\text { Annual } \\
\text { April-to-October }\end{array}$ & $\begin{array}{c}555.5 \pm 41.7 \\
390.1 \pm 40.7 \\
(70.2)\end{array}$ & $\begin{array}{c}628.5 \pm 53.8 \\
432.4 \pm 64.3 \\
(68.8)\end{array}$ & $\begin{array}{l}+13.2 \text { ** } \\
+10.8^{*}\end{array}$ \\
\hline Koigorodok & $\begin{array}{c}\text { Annual } \\
\text { April-to-October }\end{array}$ & $\begin{array}{c}570.1 \pm 33.8 \\
405.3 \pm 26.7 \\
(71.1)\end{array}$ & $\begin{array}{c}643.9 \pm 54.8 \\
439.6 \pm 49.8 \\
(68.3)\end{array}$ & $\begin{array}{l}+12.9^{* *} \\
+8.5^{*}\end{array}$ \\
\hline Kilmez' & $\begin{array}{c}\text { Annual } \\
\text { April-to-October }\end{array}$ & $\begin{array}{c}524.0 \pm 37.5 \\
363.7 \pm 29.8 \\
(69.4)\end{array}$ & $\begin{array}{c}586.5 \pm 45.7 \\
394.0 \pm 45.8 \\
(67.2)\end{array}$ & $\begin{array}{l}+11.9 \text { ** } \\
+8.3^{*}\end{array}$ \\
\hline Yelabuga & $\begin{array}{c}\text { Annual } \\
\text { April-to-October }\end{array}$ & $\begin{array}{c}534.3 \pm 58.0 \\
352.0 \pm 51.1 \\
\quad(65.9)\end{array}$ & $\begin{array}{c}533.1 \pm 33.0 \\
330.5 \pm 45.9 \\
(62.0)\end{array}$ & $\begin{array}{l}-0.2 * \\
-6.1 *\end{array}$ \\
\hline Izhevsk & $\begin{array}{c}\text { Annual } \\
\text { April-to-October }\end{array}$ & $\begin{array}{c}529.1 \pm 44.0 \\
342.3 \pm 32.3 \\
(64.7)\end{array}$ & $\begin{array}{c}569.5 \pm 49.6 \\
380.4 \pm 82.7 \\
(66.8)\end{array}$ & $\begin{array}{l}+7.6^{*} \\
+11.1^{*}\end{array}$ \\
\hline Debessy & $\begin{array}{c}\text { Annual } \\
\text { April-to-October }\end{array}$ & $\begin{array}{c}532.8 \pm 32.4 \\
376.9 \pm 30.1 \\
(70.7)\end{array}$ & $\begin{array}{c}595.3 \pm 44.6 \\
428.3 \pm 55.5 \\
(71.9)\end{array}$ & $\begin{array}{l}+11.7^{* *} \\
+13.6 \text { * }\end{array}$ \\
\hline
\end{tabular}


Table A2. Cont.

\begin{tabular}{ccccc}
\hline \multirow{2}{*}{$\begin{array}{c}\text { Meteorological Station } \\
\text { (See Figure 1) }\end{array}$} & Precipitation & \multicolumn{2}{c}{ Monitoring Period } & \multirow{2}{*}{$\mathbf{\Delta , ~ \% ~}$} \\
\cline { 3 - 4 } & & $\mathbf{1 9 6 6 - 1 9 8 0}$ & $\mathbf{2 0 1 0 - 2 0 1 9}$ & \\
\hline \multirow{2}{*}{ Perm } & Annual & $596.6 \pm 37.2$ & $702.3 \pm 81.0$ & $+17.7^{* *}$ \\
& April-to-October & $415.7 \pm 31.4$ & $490.4 \pm 71.5$ & $+18.0^{*}$ \\
& & $(69.7)$ & $(69.8)$ & \\
Cherdyn' & Annual & $711.6 \pm 68.1$ & $871.0 \pm 78.0$ & $+22.4^{* * *}$ \\
& April-to-October & $462.0 \pm 53.0$ & $564.0 \pm 67.2$ & $+22.1^{* *}$ \\
\hline
\end{tabular}

$\Delta$-relative changes between the periods. Note: The proportion (\%) of April-to-October precipitation in the annual precipitation is shown in parentheses. The statistical probability $p:{ }^{*}>0.05,{ }^{* *} 0.01-0.05,{ }^{* * *} 0.001-0.01$.

\section{Appendix C}

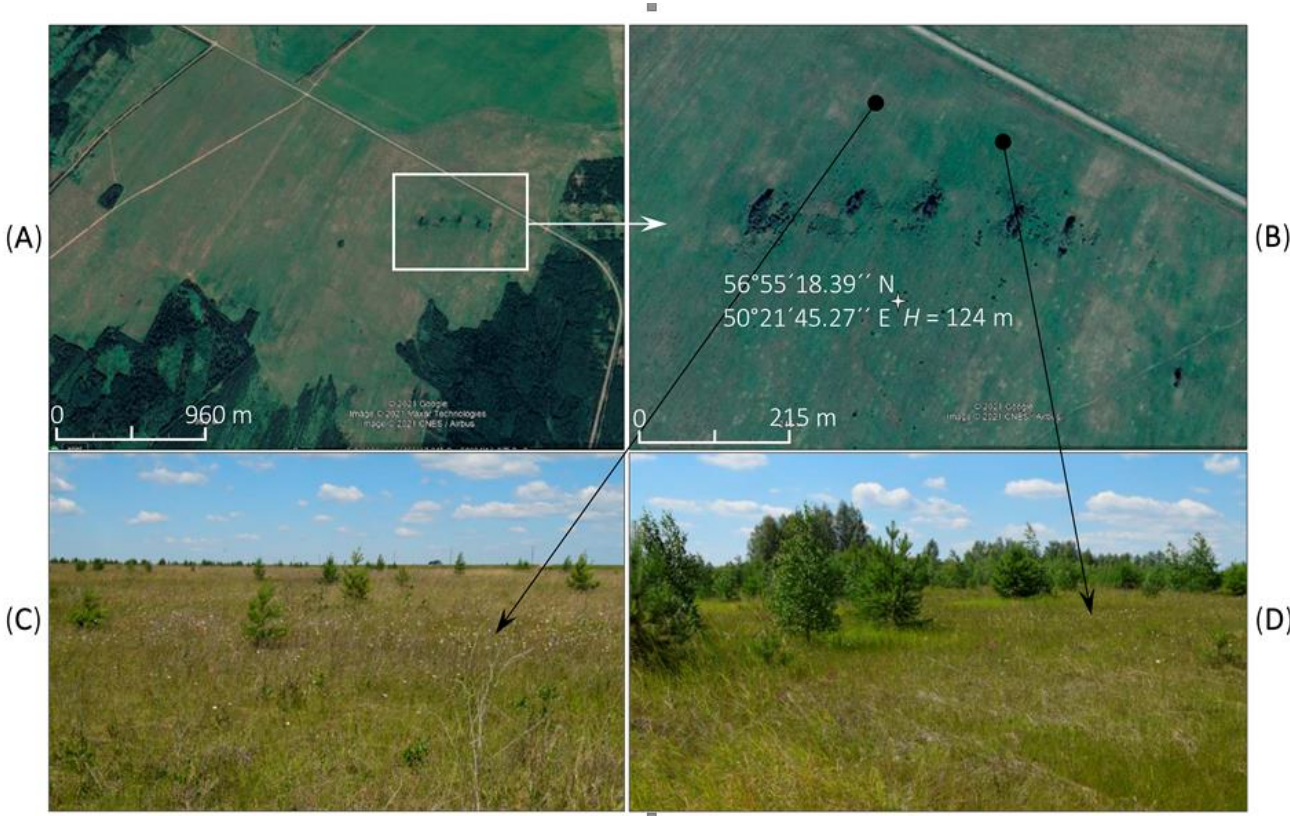

Figure A4. An example of formerly cultivated land (A,B) overgrown with herbaceous and woody (mainly Pinus sylvestris L.) vegetation (C,D) in the Urzhum District of the Kirov Oblast, European Russia. Note: Ground images, taken on June 19, 2021, show sites with different age stages of overgrowing on the cultivated land-from relatively younger (C) to somewhat older (D); according to the morphological characteristics of the growing pines, this site stopped plowing at least 10 years ago). H-the absolute elevation of the point specified. 


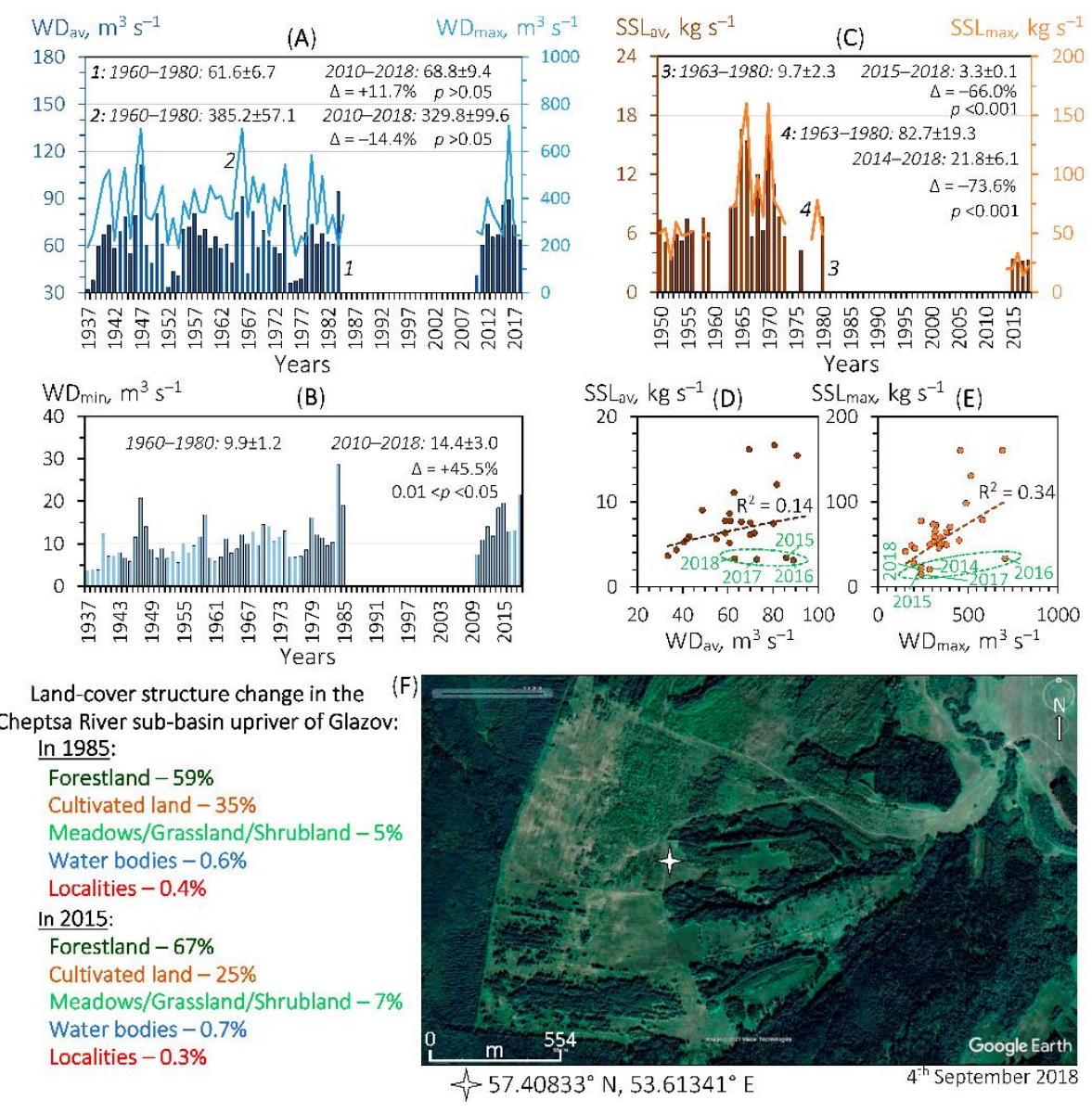

Figure A5. Contemporary changes in water discharge (WD) and suspended sediment load (SSL) of the Cheptsa River at Glazov (see Figure 1). (A)—average annual $\left(\mathrm{WD}_{\mathrm{av}}, 1\right)$ and maximum average monthly $\left(\mathrm{WD}_{\max }, 2\right) \mathrm{WD}$; (B) - minimum average monthly WD (WD $\mathrm{Win}_{\text {) }}$; (C) —average annual (SSLav, 3) and maximum average monthly (SSLmax, 4) SSL; (D)—the ratio between $\mathrm{WD}_{\mathrm{av}}$ and SSL $\mathrm{Sv}_{\mathrm{v}}(\mathbf{E})$ — the ratio between $\mathrm{WD}_{\max }$ and $\mathrm{SSL}_{\max } ;(\mathbf{F})$ —an example of overgrowing an abandoned cultivated land in the Cheptsa River basin nearby the Sursovay rural settlement, Sharkansky District of the Udmurt Republic, European Russia. $\mathrm{R}^{2}$ — the coefficient of determination of a power trend (the dashed line). Note: As shown in the charts D and E, different SSL of the Cheptsa River is within almost the same range of WD. This fact further confirms our conclusion that the comparatively low values of SSL in the 2010s were not associated with a decrease in WD but with land-use/-cover changes.

\section{References}

1. Shmakin, A.B.; Popova, V.V. Dynamics of climate extremes in Northern Eurasia in the late 20th century. Izv. Atmos. Ocean. Phys. 2006, 42, 138-147. (In Russian) [CrossRef]

2. Popova, V.V.; Polyakova, I.A. Change of stable snow cover destruction dates in Northern Eurasia, 1936-2008: Impact of global warming and the role of large-scale atmospheric circulation. Ice Snow 2013, 53, 29-39. (In Russian) [CrossRef]

3. Shvidenko, A.Z.; Schepaschenko, D.G. Climate change and wildfires in Russia. Contemp. Probl. Ecol. 2013, 6, 683-692. [CrossRef]

4. Madsen, H.; Lawrence, D.; Lang, M.; Martinkova, M.; Kjeldsen, T.R. Review of trend analysis and climate change projections of extreme precipitation and floods in Europe. J. Hydrol. 2014, 519, 3634-3650. [CrossRef]

5. Park, H.; Sherstiukov, A.B.; Fedorov, A.N.; Polyakov, I.V.; Walsh, J.E. An observation-based assessment of the influences of air temperature and snow depth on soil temperature in Russia. Environ. Res. Lett. 2014, 9, 64026. [CrossRef]

6. Anisimov, O.; Orttung, R. Climate change in Northern Russia through the prism of public perception. Ambio 2019, 48, 661-671. [CrossRef] [PubMed]

7. Perevedentsev, Y.P.; Shantalinskii, K.M.; Guryanov, V.V.; Nikolaev, A.A.; Aukhadeev, T.R. Empirical Statistical Model of Climatic Changes in the Volga Region. IOP Conf. Ser. Earth Environ. Sci. 2018, 211, 012016. [CrossRef]

8. Dolgov, S.V. Climate changes of the annual rivers' run-off and its components in the European part of Russia. Izv. Akad. Nauk Seriya Geogr. 2011, 6, 78-86. (In Russian) 
9. Frolova, N.L.; Kireeva, M.B.; Agafonova, S.A.; Yevstigneev, V.M.; Yefremova, N.A.; Povalishnikova, Y.S. Intra-annual distribution of the plain river discharges within the European Russia and its change. Water Sect. Russ. Probl. Technol. Manag. 2015, 4, 4-20. (In Russian)

10. Blöschl, G.; Hall, J.; Parajka, J.; Perdigão, R.A.P.; Merz, B.; Arheimer, B.; Aronica, G.T.; Bilibashi, A.; Bonacci, O.; Borga, M.; et al. Changing climate shifts timing of European floods. Science 2017, 357, 588-590. [CrossRef]

11. Frolova, N.L.; Agafonova, S.A.; Kireeva, M.B.; Povalishnikova, E.S.; Pakhomova, O.M. Recent changes of annual flow distribution of the Volga basin rivers. Geogr. Environ. Sustain. 2017, 10, 28-39. [CrossRef]

12. Blöschl, G.; Hall, J.; Viglione, A.; Perdigão, R.A.P.; Parajka, J.; Merz, B.; Lun, D.; Arheimer, B.; Aronica, G.T.; Bilibashi, A.; et al. Changing climate both increases and decreases European river floods. Nature 2019, 573, 108-111. [CrossRef]

13. Yermolaev, O.; Mukharamova, S.; Vedeneeva, E. River runoff modeling in the European territory of Russia. Catena 2021, 203, 105327. [CrossRef]

14. Gusarov, A.V. The response of water flow, suspended sediment yield and erosion intensity to contemporary long-term changes in climate and land use/cover in river basins of the Middle Volga Region, European Russia. Sci. Total Environ. 2020, 719, 134770. [CrossRef]

15. Sarauskiene, D.; Kriauciuniene, J.; Reihan, A.; Klavins, M. Flood pattern changes in the rivers of the Baltic countries. J. Environ. Eng. Landsc. Manag. 2015, 23, 28-38. [CrossRef]

16. Mukhin, G.D. Ecological-economic assessment of land use structure within the European territory of Russia during two recent decades. Vestn. Mosk. Univ. Ser. 5 Geogr. 2012, 5, 19-28. (In Russian)

17. Nefedova, T.G. Major trends for changes in the socioeconomic space of rural Russia. Reg. Res. Russ. 2012, 2, 41-54. [CrossRef]

18. Prishchepov, A.V.; Müller, D.; Dubinin, M.; Baumann, M.; Radeloff, V.C. Determinants of agricultural land abandonment in post-Soviet European Russia. Land Use Policy 2013, 30, 873-884. [CrossRef]

19. Lyuri, D.I.; Nekrich, A.S.; Karelin, D.V. Cropland dynamics in Russia in 1990-2015 and soil emission of carbon dioxide. Vest. Mosk. Univ. Ser. 5 Geogr. 2018, 3, 70-76. (In Russian)

20. Nekrich, A.S.; Lyuri, D.I. Changes of the dynamic of agrarian lands of Russia in 1990-2014. Izv. Ross. Akad. Nauk. Seriya Geogr. 2019, 3, 64-77. (In Russian) [CrossRef]

21. Gusarov, A.V. Land-use/-cover changes and their effect on soil erosion and river suspended sediment load in different landscape zones of European Russia during 1970-2017. Water 2021, 13, 1631. [CrossRef]

22. Litvin, L.F.; Kiryukhina, Z.P.; Krasnov, S.F.; Dobrovol'skaya, N.G. Dynamics of agricultural soil erosion in European Russia. Eurasian Soil Sci. 2017, 50, 1343-1352. [CrossRef]

23. Rysin, I.I.; Grigoryev, I.I.; Zaitceva, M.Y.; Golosov, V.N.; Sharifullin, A.G. Long-term monitoring of gully erosion in Udmurt Republic, Russia. Proc. IAHS 2017, 375, 1-4. [CrossRef]

24. Golosov, V.N. Erosion and Deposition Processes in River Basins of Cultivated Plains; GEOS Publisher: Moscow, Russia, 2006. (In Russian)

25. Atlas of the Kirov Oblast; Terekhov, N.M. (Ed.) Main Directorate of Geodesy and Cartography under the Council of Ministers of the USSR: Moscow, Russia, 1968. (In Russian)

26. Surface Water Resources of the USSR. Basic Hydrological Characteristics; The Kama River; Hydrometeoizdat: Leningrad, Russia, 1967; Volume 11, Issue 1. (In Russian)

27. Surface Water Resources of the USSR. Basic Hydrological Characteristics (for 1963-1970 and the Entire Observation Period); The Kama River; Hydrometeoizdat: Leningrad, Russia, 1975; Volume 11, Issue 1. (In Russian)

28. State Water Cadaster. Basic Hydrological Characteristics (for 1970-1975 and the Entire Observation Period); The Kama River; Hydrometeoizdat: Leningrad, Russia, 1979; Volume 11, Issue 1. (In Russian)

29. State Water Cadaster; The Kama River basin; Hydrometeoizdat: Leningrad, Russia, 1988. (In Russian)

30. Karaushev, A.V. Water erosion and sediment. In Sediment Yield, Its Study and Geographical Distribution; Karaushev, A.V., Ed.; Gidrometeoizdat Publisher: Leningrad, Russia, 1977. (In Russian)

31. The National Economy of the RSFSR in 1960 (Statistical Yearbook). "GOSSTATIZDAT-Central Statistical Bureau of the USSR" Publisher: Moscow, Russia, 1961. Available online: http:/ /istmat.info/node/20363 (accessed on 7 May 2021). (In Russian).

32. The National Economy of the RSFSR in 1970 (Statistical Yearbook). "Statistika" Publisher: Moscow, Russia, 1971. Available online: http:/ /istmat.info/node/15967 (accessed on 7 May 2021). (In Russian)

33. The National Economy of the RSFSR in 1980 (Statistical Yearbook). "Finansy i Statistika" Publisher: Moscow, Russia, 1981. Available online: http:/ / istmat.info/files/uploads/15862/narodnoe_hozyaystvo_rsfsr_v_1980g.pdf (accessed on 7 May 2021). (In Russian)

34. The National Economy of the RSFSR in 1990 (Statistical Yearbook). "Republican Information and Publishing Center" Publisher: Moscow, Russia, 1991. Available online: http:/ / istmat.info/node/15863 (accessed on 7 May 2021). (In Russian)

35. Agriculture of the USSR: Statistical Bulletin (Main Indicators of Crop Production Development). Streltsov, G.I.; Makarova, O.K.; Zhdanov, M.P. (Eds.) "Finansy i Statistika" Publisher: Moscow, Russia, 1988; Available online: http://istmat.info/node/26167 (accessed on 10 September 2020). (In Russian)

36. Dedkov, A.P.; Mozzherin, V.I. Erosion and Sediment Yield on the Earth; Kazan University Publisher: Kazan, Russia, 1984. (In Russian)

37. Bobrovitskaya, N.N. Long-term variations in mean erosion and sediment yield from the rivers of the former Soviet Union. IAHS-AISH Publ. 1996, 236, 407-413. 
38. Bakker, M.M.; Govers, G.; van Doorn, A.; Quetier, F.; Chouvardas, D.; Rounsevell, M. The response of soil erosion and sediment export to land-use change in four areas of Europe: The importance of landscape pattern. Geomorphology 2008, 98, 213-226. [CrossRef]

39. Keesstra, S.D.; van Dam, O.; Verstraeten, G.; van Huissteden, J. Changing sediment dynamics due to natural reforestation in the Dragonja catchment, SW Slovenia. Catena 2009, 78, 60-71. [CrossRef]

40. Fuchs, M.; Will, M.; Kunert, E.; Kreutzer, S.; Fischer, M.; Reverman, R. The temporal and spatial quantification of Holocene sediment dynamics in a meso-scale catchment in northern Bavaria, Germany. Holocene 2011, 21, 1093-1104. [CrossRef]

41. De Girolamo, A.M.; Pappagallo, G.; Porto, A.L. Temporal variability of suspended sediment transport and rating curves in a Mediterranean river basin: The Celone (SE Italy). Catena 2015, 128, 135-143. [CrossRef]

42. Gao, J.H.; Xu, X.; Jia, J.; Kettner, A.J.; Xing, F.; Wang, Y.P.; Yang, Y.; Qi, S.; Liao, F.; Li, J.; et al. A numerical investigation of freshwater and sediment discharge variations of Poyang Lake catchment, China over the last 1000 years. Holocene 2015, 25, 1470-1482. [CrossRef]

43. Vercruysse, K.; Grabowski, R.C.; Rickson, R.J. Suspended sediment transport dynamics in rivers: Multi-scale drivers of temporal variation. Earth Sci. Rev. 2017, 166, 38-52. [CrossRef]

44. Chalov, R.S.; Golosov, V.N.; Sidorchuk, A.Y.; Litvin, L.F.; Alexeevsky, N.I.; Chernov, A.V.; Kovalev, S.N.; Krasnov, S.F.; Larionov, G.A.; Berkovich, K.M.; et al. Catchment Erosion-Fluvial Systems; Chalov, R.S., Golosov, V.N., Sidorchuk, A.Y., Eds.; INFRA-M Publisher: Moscow, Russia, 2017. (In Russian)

45. Dedkov, A. The relationship between sediment yield and drainage basin area. IAHS Publ. 2004, 288, 197-204.

46. Fryirs, K.A. (Dis)Connectivity in catchment sediment cascades: A fresh look at the sediment delivery problem. Earth Surf. Process. Landf. 2013, 38, 30-46. [CrossRef]

47. Larsen, A.; Heckmann, T.; Larsen, J.R.; Bork, H.-R. Gully catchments as a sediment sink, not just a source: Results from a long-term ( 12,500 year) sediment budget. Earth Surf. Proc. Landf. 2016, 41, 486-498. [CrossRef]

48. Sidorchuk, A.Y. The fluvial system on the East European plain: Sediment source and sink. Geogr. Environ. Sustain. 2018, 11, 5-20. [CrossRef]

49. Wischmeier, W.H.; Smith, D.D. Predicting Rainfall Erosion Losses Agriculture Handbook 537; U.S. Department of Agriculture Publisher: Washington, DC, USA, 1978.

50. Chernokulsky, A.; Kozlov, F.; Zolina, O.; Bulygina, O.; Mokhov, I.I.; Semenov, V.A. Observed changes in convective and stratiform precipitation in Northern Eurasia over the last five decades. Environ. Res. Lett. 2019, 14, 045001. [CrossRef]

51. Mozzherin, V.I.; Kurbanova, S.G. Human Activities and Erosion and Riverbed Systems of the Middle Volga Region; ART DESIGN Publisher: Kazan, Russia, 2004. (In Russian)

52. Solodyankin, N.M. The Kirov Oblast in 1950-1990. Economic problems. In The encyclopedia of Vyatka Land. History; Sitnikov, V.A., Ed.; "Vyatka” Publisher: Kirov, Russia, 1995; Volume 4, pp. 421-436.

53. Mulholland, B.; Fullen, M.A. Cattle trampling and soil compaction on loamy sands. Soil Use Manag. 1991, 7, 189-193. [CrossRef]

54. Donkor, N.T.; Gedir, J.V.; Hudson, R.J.; Bork, E.W.; Chanasyk, D.S.; Naeth, M.A. Impacts of grazing systems on soil compaction and pasture production in Alberta. Can. J. Soil Sci. 2002, 82, 1-8. [CrossRef]

55. Gusarov, A.V.; Rysin, I.I.; Sharifullin, A.G.; Golosov, V.N. Assessment of contemporary erosion/sedimentation rates trend within a small cultivated catchment using the radiocaesium-137 as a chronomarker (a case study from the Udmurt Republic, European Russia). Geomorfologiya 2019, 2, 37-56. [CrossRef]

56. Golosov, V.N.; Gennadiev, A.N.; Olson, K.R.; Markelov, M.V.; Zhidkin, A.P.; Chendev, Y.G.; Kovach, R.G. Spatial and temporal features of soil erosion in the forest-steppe zone of the East-European Plain. Eurasian Soil Sci. 2011, 44, 794-801. [CrossRef]

57. Markelov, M.V.; Golosov, V.N.; Belyaev, V.R. Changes in the sedimentation rates on the floodplains of small rivers in the Central Russian Plain. Vestn. Mosk. Univ. Ser. 5 Geogr. 2012, 5, 70-76. (In Russian)

58. Gusarov, A.V. The impact of contemporary changes in climate and land use/cover on tendencies in water flow, suspended sediment yield and erosion intensity in the northeastern part of the Don River basin, SW European Russia. Environ. Res. 2019, 175, 468-488. [CrossRef]

59. Gusarov, A.V.; Sharifullin, A.G. Contemporary erosion and suspended sediment yield within river basins in the steppe of the southeastern part of the Russian Plain: A case study of the Samara River basin. Izv. Ross. Akad. Nauk Seriya Geogr. 2019, 1, 37-51. (In Russian) [CrossRef]

60. Gusarov, A.V.; Sharifullin, A.G.; Komissarov, M.A. Contemporary long-term trends in water discharge, suspended sediment load, and erosion intensity in river basins of the North Caucasus region, SW Russia. Hydrology 2021, 8, 28. [CrossRef]

61. Buryak, Z.; Marinina, O. Using GIS technology for identification of agricultural land with an increased risk of erosion. E3S Web Conf. 2020, 176, 04007. [CrossRef]

62. Shtompel, Y.A.; Lisetskii, F.N.; Sukhanovskii, Y.P.; Strelnikova, A.V. Soil loss tolerance of brown forest soils of Northwestern Caucasus under intensive agriculture. Eurasian Soil Sci. 1998, 31, 185-190.

63. Gusarov, A.V. The main regularities of the ratio between riverbed and basin components of erosion and suspended sediment flux in the Northern Eurasia's river basins. Geomorfologiya 2015, 4, 3. [CrossRef] 